Pregledni članak UDK 113/119(045) Bošković, R. doi: $10.21464 /$ fi 39302 Primljeno: 17. 7. 2019.

\author{
Marito Mihovil Letica \\ Lopatinečka 15, HR-10000 Zagreb \\ marito.mihovil.letica@gmail.com
}

\title{
Znanstveno-tehnički dosezi Boškovićeva metafizičkog prirodoslovlja
}

\begin{abstract}
Sažetak
U ovom se radu ističe i argumentira da je Boškovićeva prirodoznanstvena teorija toliko ukorijenjena u metafizici i njome prožeta da se može ustanoviti kako je posrijedi osobiti primjer oštroumnog, domišljenog i dalekosežnog metafizičkog prirodoslovlja. Kritički se osvrćući na neutemeljena osporavanja metafizike $i$ višestoljetne pokušaje njezina nadvladavanja, autor pokazuje da je Bošković metafizičkim mišljenjem u 18. stoljeću dospio do svog pojma jedinstvene privlačno-odbojne sile te proniknuo u strukturu tvari, čime je anticipirao, uz ostalo, teoriju relativnosti i kvantnu fiziku. Premda se Bošković izdašno i uspješno služio kvantitativnim metodama pri rješavanju problemâ iz geodezije, astronomije, optike, građevinske statike, hidrotehnike itd. - najznačajniji dijelovi njegove prirodoznanstvene ostavštine, kojima se transponirao stoljeće ili dva ispred svojega vremena, podržani su geometrijskom intuicijom $i$ provedeni poglavito kvalitativnom metodom, odnosno metafizičkom spekulacijom. Autor $k$ tome objašnjava da se za nastanak $i$ razvoj elektromagnetizma odlučujućim pokazalo opisivanje elektromagnetskih pojava s pomoću Boškovićeve jedinstvene sile i njegove teorije o građi tvari, što je u posve određenom smislu istaknuo 'otac elektromagnetizma' James Clerk Maxwell; a do tih prirodoznanstvenih ideja Bošković nije dospio utječući se egzaktnom znanstvenom pristupu, nego metafizički zasnovanom $i$ vođenom 'ispravnom razmišljanju'.
\end{abstract}

\section{Ključne riječi}

Ruđer Josip Bošković, metafizika, znanost, sila, tvar, teorija relativnosti, kvantna fizika

\section{Uvod: o metafizici i prijeporima oko njezina mjesta u povijesti filozofije}

»Svi ljudi teže znanju po naravi ${ }^{1}{ }^{1}$ rečenica je kojom se otvara Metafizika, prema mišljenjima brojnih znalaca i mjerodavnika najsloženije i najdublje Aristotelovo djelo te najvažniji i najdalekosežniji spis cjelokupne antičke filozofije. Za navedenu rečenicu možemo samo nagađati slučajno li se ili namjerno našla na samome početku Metafizike, ali ne podliježe sumnji da je Aristotel njome izrazio jedno od temeljnih čovjekovih obilježja, njegovih specifičnosti, antropina. Iz rečene težnje za znanjem rođene su filozofija i znanost, a one se sve do novovjekovlja iskazuju jednim i nerazdvojivim korpusom znanja.

Valja podsjetiti da pojam metafizika etimološki dospijeva od složenice metá

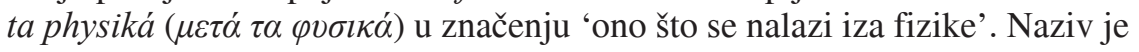


navodno ${ }^{2}$ skovao Andronik s Roda u 1. stoljeću prije Krista, a odnosio se dotični pojam na skupinu knjiga što ih je u izdanju Aristotelovih djela Andronik postavio iza njegovih spisa o fizici. ${ }^{3}$ Ta je skupina djelâ danas poznata pod imenom Metafizika.

Zajedno s Aristotelom možemo metafiziku u općenitom smislu odrediti kao temeljnu filozofijsku disciplinu. Ovaj velikan filozofskoga mišljenja naziva je 'prvom filozofijom' i drži je 'božanskom znanošću', a teologija (koju ne bismo smjeli razumijevati u suvremenome smislu te riječi) prema njegovu je mišljenju vrhunac metafizičkoga procesa spoznavanja. Aristotelova 'prva filozofija' ili metafizika bavi se onim što je onostrano u odnosu na fizički svijet. Riječ je o sadržajima koji su temeljni principi i uzroci svega postojećeg; bilo to postojeće iskustvu dostupno ili nedostupno. U dosluhu s Aristotelom možemo uvjereno ustvrditi da je znanost koja proučava prve uzroke ujedno znanost koja razmatra biće kao biće. ${ }^{4}$

No sudbina je metafizike da su razumijevanja i vrednovanja njezina pojma bila od samih početaka podložna promjenama. Nerijetko se kroz povijest filozofije pojam metafizika rabio kao naziv za filozofiju u općenitom smislu, gdjekad i kao sinonim za ontologiju, a napose je pojmom metafizika bivala označena težnja da se spekulativnim putem dospije do istine o bîti svijeta, da se spozna njegova usebnost, ali i onostranost. Bilo je i različitih podjela metafizike. Spomenut ću samo onu racionalista Christiana Wolffa, koji je u prvoj polovici 18. stoljeća metafiziku podijelio, uzimajući u obzir tradiciju antičkih i skolastičkih metafizičkih tema, na opću (ontologija) te specijalnu (teologija, kozmologija i psihologija).

Danas je, nažalost, znanje o metafizici takvo da ga, uz rijetke iznimke, možemo tipološki svrstati u tri skupine: 1. izostanak ikakvoga znanja; 2. oskudno znanje i/ili iskrivljeno poimanje; 3. tematsko i respektabilno znanje, ali s pogrešnim zaključcima.

Naime, možemo reći da postoji stanovit broj onih koji o metafizici ništa ne znaju, a to gotovo u pravilu i priznaju, ali ih ipak složeni pojam meta-fizika zbog uključene riječi fizika misleno navodi na nešto što bi moglo imati određene veze sa znanošću. Zanimljivo je da se oni u svojem neznanju, odnosno netematskom shvaćanju, zatječu na dobrome tragu. Nadalje, ima znatan broj ljudi koji su uvjereni da o metafizici nešto znaju, brkajući je pritom s kojekakvim pomodnim pojavama proisteklima iz sinkretističkoga i razgranatoga pokreta New age: s brojnim varijantama 'transcendentalne meditacije', zatim s ezoterijskim učenjima, pseudo-mistikom, praksama koje dovode do oslobođenja i prosvjetljenja itd. Napokon, u treću skupinu dolaze oni čije je znanje o metafizici vrijedno pozornosti. Premda metafiziku ne poistovjećuju s nečim što ona nije niti je ikada bila, oni u tom tematskom razumijevanju njezina pojma i mjesta u povijesti filozofije smatraju metafiziku nečim što je odavno nadvladano, nečim što nije ništa drugo doli relikt prošlosti. Za ove potonje možemo ustanoviti da griješe s platforme znatno veće upućenosti, odnosno da je njihova pogrešna ocjena na znatno višoj spoznajnoj razini od svjesnoga neznanja prvih i nesvjesnoga zastranjenja drugih. No odbacivanje metafizike nije pojava vezana isključivo za naše doba; takva su stajališta duga vijeka i daha.

Usuprot aristotelovsko-skolastičkomu esencijalističkom ${ }^{5}$ pristupu prirodnim pojavama (dakle metafizičkom pristupu), uspinje se u 17. stoljeću na scenu Baconova indukcija, kao nova znanstvena paradigma. Francis Bacon predlaže metodu u okviru koje polazi od pojava ili učinaka što ih otkrivamo sustavnim opažanjem i eksperimentiranjem te uklanjanjem zapreka i zabluda (idola) 
dospijevamo do dubljih uzroka, tj. znanja o prirodi i svijetu. Prema Baconovu mišljenju, nova znanstvena metoda ne smije biti utemeljena na deduktivnome zaključivanju i matematici.

Baconov trideset i više godina mlađi suvremenik René Descartes u prvoj se polovici 17. stoljeća utječe upravo deduktivnoj logici i matematici (utemeljitelj je analitičke geometrije). Uzima stablo kao metaforu za ljudsko znanje: cjelokupna znanost je stablo kojemu je metafizika korijen, fizika deblo, a ostale discipline poput mehanike, etike, geometrije i medicine predstavljene su granama na kojima izrastaju plodovi. No kartezijanski na matematici zasnovan racionalizam donosi instrumentalnu racionalnost $\mathrm{u}$ ambijentu koje kozmos prestaje biti razumijevan kao nositelj smislenoga reda ili poretka (ordo) i teleološke svrhovitosti, na temelju čega čovjek može spoznati objektivni red bitka - a promeće se u svijet shvaćen kao mehanizam. ${ }^{6}$ Sve se, smatra Descartes, kreće po zakonima mehanike, pa tako i živa bića. U djelu Rasprava o metodi Descartes kaže da je

»... moguće doći do spoznaja, koje su za život veoma korisne, i da se mjesto ove spekulativne filozofije [metafizike; op. M. M. L.], koja se uči u školama, može naći praktična, pomoću koje bismo tako točno upoznali snagu i djelovanje vatre, vode, zraka, zvijezda, nebeskog svoda i svih drugih tijela koja nas okružuju, kao što poznajemo različite stručne vještine naših obrtnika, i mogli ih na isti način upotrebljavati u sve svrhe, za koje su prikladna, te tako postati gospodarima i vlasnicima prirode. $\ll^{7}$

U 18. stoljeću Immanuel Kant izvodi metafiziku pred sudište razuma te joj, unatoč nedostatku vjerodostojnih dokaza i suprotno svojoj prvotnoj namjeri, izriče presudu. U predgovoru drugom izdanju Kritike čistog uma kaže da me-

Prvi je Immanuel Kant u 18. stoljeću posumnjao da pojam metafizika potječe od Andronika s Roda. U jednome predavanju o metafizici Kant ističe kako »ne bi trebalo vjerovati da je naziv djela Metafizika nastao slučajno, budući da naziv točno odgovara naravi te znanosti $\ll$. O tome se više može pročitati u djelu: Max Heinze, Vorlesungen Kants über Metaphysik aus drei Semestern, Kessinger Publishing, Whitefish 2010. Nadalje, Hans Reiner objavljuje dvije podrobne studije da bi dokazao kako naslov Metafizika zaista nije nastao slučajno, nego da je iz didaktičko-sistematskih razloga uveden već za vrijeme rane aristotelovske tradicije, te da uvjerenje o Andronikovu 'bibliotekarskom podrijetlu' toga imena spada u legendu. Citirajući Aleksandra Afrodizijskoga koji kaže da je upravo Aristotel ovu znanost nazvao metafizikom jer po redu za nas dolazi nakon fizike, Reiner dokazuje da je sámo Aristotelovo shvaćanje naravi spoznaje, prema kojemu ono 'po sebi' unutar spoznajnoga procesa dolazi nakon onoga 'za nas', bilo odlučujuće da predavanja posvećena 'prvim uzrocima' budu naslovljena Metafizika. Podrobnije o podrijetlu pojma metafizika usp. Marijan Cipra, Metamorfoze metafizike, Matica hrvatska, Zagreb 1999., str. 24 (bilj. 7).

3

Usp. Alois Halder, Filozofijski rječnik, preveo Ante Sesar, Naklada Jurčić, Zagreb 2002., str. 215.
4

Usp. Michael J. Loux, Metafizika. Suvremen uvod, preveo Zvonimir Čuljak, Sveučilište u Zagrebu - Hrvatski studiji, Zagreb 2010., str. 17.

Latinski pojam essentia ustvari je skolastički prijevod Aristotelova i aristotelovskog izraza

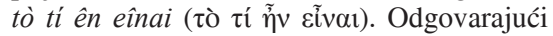
hrvatski izrazi za ovaj pojam jesu: bît, bitstvo, suće, sućina, suština. Posrijedi je jedna od osnovnih filozofijskih kategorija, unutarnji princip bića, ono što postavlja biće u bitak i po čemu je biće to što jest. Bît nije dovoljna za samostalno formiranje nekog bića, nego pretpostavlja 'čin bitka' ili 'čin bivovanja' (actus essendi). Ta su dva principa u konkretnom biću stvarno ujedinjena, a razlikuju se metafizički.

6

Usp. Tonči Matulić, Metamorfoze kulture. Teološko prepoznavanje znakova vremenâ u ozračju znanstveno-tehničke civilizacije, Glas Koncila, Zagreb 2008., str. 509-510.

7

René Descartes, Rasprava o metodi, preveo Niko Berus, Matica hrvatska, Zagreb 1951., str. 50. 
tafizici kao 'izoliranoj spekulativnoj znanosti koja nadilazi svako iskustvo' sudbina nije bila sklona da bi, za razliku od matematike, mogla kročiti sigurnim putem znanosti. U metafizici, uvjeren je Kant, um neprestano posustaje, čak i kada bi htio ònē zakone koje potvrđuje najobičnije iskustvo spoznati $a$ priori - i stoga dosadašnja nastojanja metafizike nisu bila, zaključuje Kant, ništa više doli 'lutanje među samim pojmovima' ${ }^{8}$

Kant uspoređuje metafiziku s golubicom kojoj se čini da bi mogla lakše i brže letjeti kada ne bi bilo otpora zraka koji je u letu usporava; a ne uviđa ta golubica da u odsutnosti zraka, koji njezinim krilima omogućava potisak, uopće ne bi mogla letjeti. Zrak koji metafizici nedostaje, smatra Kant, upravo su iskustvene činjenice. Duboko svjestan da objektivna znanstvena spoznaja, odnosno prirodna znanost, ipak ne može biti zasnovana samo na iskustvu, Kant u svojevrsnoj kritičkoj sintezi nastoji pomiriti suprotstavljenosti empirizma i racionalizma. Smatra da od jednog i drugog pristupa valja uzeti ono što je istinito i korisno - što naposljetku dovodi do napretka znanosti. ${ }^{9}$

Kantova racionalistička sastavnica najsnažnije progovara kroz činjenicu da on svoju spoznajnoteorijsku metodu naziva transcendentalnom i pod time razumijeva utvrđivanje transcendentalnih, o iskustvu neovisnih, apriornih, objektivnih i nužnih uvjeta spoznaje. ${ }^{10} \mathrm{U}$ predgovoru djela Metafizički početni razlozi prirodne znanosti, želeći razlučiti ispravne postupke zasnivanja prirodne znanosti od svega što je s takvim postupcima nespojivo, Kant tvrdi da prava prirodna znanost koja hoće biti apodiktički sigurna mora uključivati matematiku. Naime, takva znanost zahtijeva jedan čisti dio koji nije zasnovan samo na iskustvu i koji se nalazi u temeljima onog empirijskog. U tomu zahtjevu Kant se oslanja na spoznaju prirodnih stvari a priori, odnosno na spoznaju neke stvari iz njezine čiste mogućnosti. U svojoj transcendentalnoj filozofiji vraća ontologiji kao 'specijalnoj metafizici', a nju razumijeva kao nauk o neposrednim predmetima ljudskoga iskustva koji su spoznatljivi unutar prostora i vremena kao oblikâ opažanja, odnosno apriornih formi zornosti.

Po dugačkome vremenskom luku prelijećemo u 20. stoljeće i dolazimo do filozofije o bitku Martina Heideggera, u kojoj je bespridržajno odbačena cjelokupna metafizika aristotelovsko-skolastičke tradicije, s obrazloženjem da je pogrešno pristupila 'ontološkoj diferenciji', tj. razlici i odnosu između bitka i bića. Heidegger smatra da aristotelovsko-skolastička metafizika govori samo o biću, a bitak je posve lakomisleno i neuviđavno zapostavila, zaboravljajući da upravo bitak čini bića bićima, da bića nisu ništa drugo nego dogodljiva uposebljenja nužnoga bitka. Tako je, uvjereno će Heidegger, moguće govoriti o 'zaboravu bitka', a posljedično i o 'nadvladavanju i završetku metafizike'. A na drugim mjestima kaže Heidegger da je metafizika 'temeljni događaj zapadnoga mišljenja' i 'usud Zapada'. ${ }^{11}$

\section{Status quaestionis: Je li Ruđer Bošković antimetafizičar ili metafizičar?}

Čini se da su nekovrsne antimetafizičke predrasude i mnogo puta tijekom povijesti filozofije i znanosti oživljavani govor o 'nadvladavanju metafizike' opteretili i pisca leksikonskoga članka o Ruđeru Boškoviću. Naime, u Hrvatskome općem leksikonu možemo pročitati među inim i ovo:

»B. je najveći hrv. učenjak svojega doba, istaknut prethodnik moderne fizikalne znanosti, utemeljitelj dinamičke atomistike; kritičar skolastičkih i metafizičkih zabluda na području prirod- 
nih znanosti. Filozofija prirode; O sunčevim pjegama; Radovi iz optike i astronomije; Elementi opće matematike; $O$ djeljivosti tvari i počelima tijela. ${ }^{12}$

O Boškoviću vrlo slično, na mjestima i posve jednako, piše i Veliki školski leksikon:

»... izgradio novu teoriju sile koja među točkama što tvore tijela djeluje privlačno na većoj udaljenosti, a odbojno na manjoj; ta je teorija potaknula centralni spor Newtona i Leibniza te utjecala na naraštaje eng. i škot. fizičara i kemičara. Kritičar skolastičkih i metafizičkih zabluda na području prirodnih znanosti; zastupao stajalište o relativnosti ljudske spoznaje. Gl. djelo: Teorija prirodne filozofije. $\ll^{13}$

Navedeni članci u skladu s leksikonskom konciznošću donose samo osnovne podatke - koji su većim dijelom istiniti. Dakle, ne i posve istiniti. Naime, Veliki školski leksikon kaže da je Boškovićeva teorija sile "potaknula centralni spor Newtona i Leibniza«. Ostaje nejasno što se time zapravo smjeralo kazati, uzme li se u obzir faktografija koja se odnosi na puku kronologiju: u trenutku Leibnizove smrti Bošković je bio dubrovački dječarac u dobi od pet godina, a u trenutku Newtonove smrti šesnaestogodišnji mladac, jezuitski gojenac u Rimu. Nedvojbeno umjesnom iskazuje se primjedba da je Boškovićeva teorija sile nastala nekoliko desetljeća nakon Newtonove i Leibnizove smrti pa ni u kojem slučaju nije mogla potaknuti njihov međusobni spor. Valja ipak u ovoj pojedinosti dobrohotno i uviđavno pretpostaviti da se u Velikom školskom leksikonu potkrala trivijalna omaška u pamćenju (lapsus memoriae) ili možda pogreška u pisanju (lapsus calami), a ne možemo do kraja isključiti ni mogućnost pogreške pri korekturi teksta i njegovoj pripremi za tiskanje.

Ali ono što se u citiranim člancima očituje ne samo problematičnim nego i krajnje neprihvatljivim jest tvrdnja da je Bošković bio »kritičar skolastičkih i metafizičkih zabluda na području prirodnih znanosti«. Tu tvrdnju, formuliranu u doslovce identičnom izričaju, nalazimo u oba leksikona. Zato nije neutemeljeno pomisliti da je obama leksikonskim člancima pisac ista osoba. Ako su pak članke kojim slučajem napisali različiti autori, onda je jedan od njih lagodno i nekritički preuzeo neistinitu tvrdnju zatečenu u prije objelodanjenom leksikonu.

Iz navedene sporne formulacije nije lako u prvi mah, a doduše ni nakon duljeg i dubljeg razmišljanja, razabrati želi li ona sugerirati da je Bošković bio kritičar skolastičkih i metafizičkih uvjerenja koja zato što su metafizička i skolastička već samim time pridolaze među zablude, ili ova formulacija hoće

8

Usp. Immanuel Kant, Kritika čistog uma, preveo Viktor D. Sonnenfeld, Nakladni zavod Matice hrvatske, Zagreb 1984., str. 14.

Usp. Mirko Jakić, Filozofija o znanosti, Hrvatsko filozofsko društvo, Zagreb 1989., str. 30-31.

10

Apriornost ili da je nešto a priori za Kanta ne znači vremensko prethođenje iskustvu; nego podrazumijeva općost i nužnost koja je neovisna o iskustvu, koja premašuje iskustvo, jer da se na njemu ne može zasnovati. Stoga se apriornost ne iskazuje kao nekakva psihologijska, nego kao posve spoznajnoteorijska oznaka. To je ključno za pravilno razumijevanje Kantova transcendentalnog idealizma.
Usp. Wilhelm Windelband, Povijest filozofije, sv. 2, Naprijed, Zagreb 1987., str. 107.

11

Usp. Martin Heidegger, »Što je metafizika?«, u: Martin Heidegger, Kraj filozofije i zadaća mišljenja. Rasprave i članci, preveo Marijan Cipra, Naprijed, Zagreb 1996., str. 83-127, str. 94; Martin Heidegger, Bitak i vrijeme, preveo Hrvoje Šarinić, Naprijed, Zagreb 1985., str. 1.

12

August Kovačec (ur.), Hrvatski opći leksikon, Leksikografski zavod »Miroslav Krleža«, Zagreb 1996., str. 114.

13

Josip Šentija (ur.), Veliki školski leksikon, Školska knjiga, Zagreb 2003., str. 126. 
tvrditi da je Bošković bio kritičar samo onih metafizičkih i skolastičkih uvjerenja koja su zaista mogla biti zablude. Nije moguće utemeljeno zanijekati okolnost da je skolastika imala stanovitih zabluda - uostalom, zabluda nije manjkalo i kod najodličnijih umova u antici, renesansi, novovjekovlju, sve do suvremene filozofije i znanosti - ali nije jasno koje su to metafizičke zablude skolastičke provenijencije bile predmetom Boškovićevih kritika. Uostalom, koji su epistemološki kriteriji i koje polazno iskustvo omogućili da, bilo od Boškovića ili od nekoga drugog kritičara, metafizičke tvrdnje budu spoznate i označene zabludama?

Jer istinitost određenoga suda koji iskazuje da je neka metafizička tvrdnja zabluda, nije moguće iskustveno verificirati. Zato je sâm taj sud nekovrsna metafizička tvrdnja. Neka mi poštovani autor (poštovani autori) leksikonskih članaka ne zamjeri (ne zamjere) na izravnosti i možebitnoj netaktičnosti, ali uzimam pravo ustanoviti da njegova (njihova) tvrdnja - za razliku od metafizičkih promišljenih tvrdnji - nije smislena, nego posve besmislena. I to ne stoga što ju je nekakva naknadna iskustvena provjera uzmogla opovrgnuti - nego zbog jednostavnog razloga što stoji sama sa sobom u nepomirljivu protuslovlju.

Već se stoljećima s materijalističkih pozicija događaju borbena obrušavanja na metafiziku i skolastiku, nesmiljeni napadi na sve što materijalistima neugodno i zazorno miriše, slikovito kazano, ne samo po neprovjetrenoj ustajalosti nego i po tamjanu. Akteri tih napada u svojemu tobožnjem prosvjetiteljskom i znanstveničkom poslanju ne uviđaju da zapravo pomućuju pogled na mnogostruke i višestruko uvjetovane aspekte zbilje, umjesto da taj pogled rasvijetle i razbistre, da im pogled u isti mah bude 'progled'. S druge bi se strane moglo s pravom ustanoviti da je Bošković cijenio i prihvaćao metafiziku otvoreno i obuhvatno, posebice kada je riječ o njegovu učenju koje se dohvaća kompleksnih pitanja prostora, vremena i materije. Premda Bošković nije autor ni jednoga djela koje bi se posebno bavilo metafizikom, izuzme li se »Dodatak « u okrilju Teorije prirodne filozofije koji govori o duši i Bogu, metafizička pitanja su poput najsuptilnijih niti utkana u njegova prirodoznanstvena djela. Filozof znanosti Stipe Kutleša objašnjava: »Boškovićeva metafizika nije klasična metafizika, nego njegova specifična 'prirodoslovna metafizika' (ili 'metafizičko prirodoslovlje'). Ona se najjasnije očituje u njegovoj teoriji privlačno-odbojnih sila i strukture tvari.«14

S obzirom na Boškovićev odnos prema aristotelovsko-skolastičkoj tradiciji, moguće je ustanoviti da tu stvari stoje nešto drukčije; ali nipošto bitno drukčije. Naime, ne može se utemeljeno zanijekati da je Bošković stanovita aristotelovsko-skolastička učenja smatrao zastarjelim te se zauzimao za njihovo obazrivo napuštanje uz istodobno približavanje Newtonovu učenju, objašnjavajući kako je peripatetička prirodna filozofija u određenim dijelovima prevladana i da nekritičko ostajanje uz njezine skute može štetiti ne samo razvitku znanstvene misli nego i katoličkoj vjeri, koju aristotelizam uz neke druge nepovoljne pretpostavke može dovesti u opasnost da je u konačnici približi materijalizmu i ateizmu. ${ }^{15}$

Imajući u obzoru okolnost da su afirmativne činjenice o metafizici i skolastici često prešućivane i iskrivljivane, ovdje bez svake preuzetnosti namjeravam argumentirano dokazati kako Ruđer Bošković ne samo da nije bio njihov protivnik nego je, upravo suprotno tim nespretnim i možda tendencioznim leksikografskim i inim krivotvorinama, aristotelovsko-skolastičkim metafizičkim pristupom dospio do vizionarskih teorija odnosno dalekosežnih anticipacija 
koje su unutar znanstvene zajednice (vjero)dostojno potvrđene sto, dvjesto i više godina nakon njegova života, uz ostalo u teoriji relativnosti i kvantnoj fizici.

Iznosim i na stranicama ovoga rada nastojim obrazložiti i opravdati tvrdnju koja će se zasigurno mnogima učiniti pretencioznom, provokativnom, čak i grotesknom: za nastanak i razvoj elektromagnetizma - čemu dugujemo iznalaske radija, televizora, aparatâ tzv. bijele tehnike, mikrovalne pećnice, lasera, rendgenskog aparata, elektroničkog računala, mobitela i drugih stečevina koje se iskazuju plodovima strelovitoga znanstveno-tehničkog napretka - odlučujuće je bilo opisivanje elektromagnetskih pojava s pomoću Boškovićeve jedinstvene sile i njegove teorije o građi tvari, ${ }^{16}$ što je u posve određenom smislu istaknuo 'otac elektromagnetizma' James Clerk Maxwell. A do tih prirodoznanstvenih ideja Bošković nije dospio utječući se egzaktnom znanstvenom pristupu fizičkim pojavama, nego metafizičkoj spekulaciji. Spomenute aparate i tehnička pomagala mogli bismo u posve određenome smislu smatrati opredmećenim i svrsishodnim odjecima starih metafizičkih ideja u svakodnevnome životu suvremenoga čovjeka.

\section{Dva polazišta Boškovićeve prirodne filozofije}

U 18. stoljeću, pa tako i u Boškovića, još ne postoji trijada metafizika - prirodna filozofija - prirodna znanost, nego je ustvari riječ o jednoj $i$ jedinstvenoj filozofijskoj, odnosno znanstvenoj disciplini. U okrilju te obuhvatne discipline Bošković se izdašno i uspješno služi kvantitativnim metodama, tj. mjerenjima i proračunima, pri rješavanju problemâ iz geodezije, astronomije, optike, građevinske statike, hidrotehnike itd. - ali najznačajniji dijelovi Boškovićeve prirodoznanstvene ostavštine, kojima se transponirao stoljeće ili dva ispred svojega vremena, proizlaze iz njegovih čistih spekulativnih razmatranja svojstvenih metafizičkom pristupu onim zakonitostima pojavnoga svijeta koje ustrajno izmiču čovjekovim osjetilima.

Dotični Boškovićev metafizički pristup, odnosno metodologija njegova prirodoznanstvenoga spoznajnoteorijskog puta ima dva polazišta, 'dva putokaza': jednostavnost $i$ analogiju (sličnoznačnost) prirode (simplicitas et analogia naturae) te princip (zakon) kontinuiteta (principium continuitatis). Bošković ih naziva 'izravnim dokazima a priori' (prove dirette a priori), što znači da je njegova teorija u samoj svojoj osnovi apriorno utemeljena. ${ }^{17}$ Prihvativši od Newtona načelo jednostavnosti i sličnoznačnosti, Bošković ga smatra temelj-

14

Stipe Kutleša, Filozofija Ruđera Boškovića, KruZak, Zagreb 2012., str. 90.

15

Još za Boškovićeva života postoje među isusovcima u Collegium Romanum dvije struje: jedna tradicionalno vjerna aristotelizmu i druga, koja traži mogućnost zaokreta u duhu Newtonova učenja. Ne samo Bošković nego i mnogi isusovački profesori diljem Europe prihvaćaju njutonizam. Najčešće je to sluča u austrijskim zemljama pa tako i među znatnim brojem profesora u Zagrebu, predavačâ na isusovačkoj Neoacademia Zagrabiensis (inače kolijevci današnjega Sveučilišta u Zagrebu).
16

To nipošto ne znači da bez Boškovića i njegovih ideja ne bi nekim drugim putem došlo do razvitka elektromagnetizma, nego samo znači da se taj razvitak slijedom okolnosti u povijesti filozofije odnosno znanosti dogodio uvelike zahvaljujući Boškovićevim prirodofilozofijskim predoblicima i anticipacijama.

17

Usp. Stipe Kutleša, Prirodnofilozofijski pojmovi Ruđera Boškovića, Hrvatsko filozofsko društvo, Zagreb 1994., str. 34. Da je nešto a priori (za razliku od a posteriori) znači da to nešto dolazi prije (ovo 'prije' ne treba shvatiti jednostavno u vremenskom smislu) Distinkcija 'a priori - a posteriori' izvorno 
nijim i od samoga načela neprekinutosti iz kojega je izravno izveo svoj zakon sila. U Teoriji prirodne filozofije Bošković o zakonu kontinuiteta kaže:

»Ja sam, jer sam ga prvi istražio, smatrao da ga nije moguće mimoići ako se hoćemo poslužiti onom jedinstvenom sličnošću prirode i snagom indukcije $(\ldots) . \ll^{18}$

Uzevši u plodonosnu daljnju razradu Aristotelovo i Leibnizovo poimanje kontinuiteta, Bošković izgrađuje svoje osebujno stajalište o neprekinutosti i s tako nastalih pozicija odbacuje još od antike baštinjenu tvrdnju o pravcu kao najjednostavnijoj krivulji, čime snažno uzdrmava klasično euklidsko i arhimedsko shvaćanje pravca. ${ }^{19}$ Tako otvara put spektru različitih mišljenjâ koja ce kasnije iznjedriti logički koherentne, ali neintuitivne geometrije poznate još od 19. stoljeća kao neeuklidske. ${ }^{20}$

Odbacivši načelo dovoljnog razloga u Leibnizovoj i lajbnicijanskoj interpretaciji, Bošković neprekinutost dokazuje dvama drugim dokazima: jedan se zasniva na metafizičkim načelima, ${ }^{21}$ a drugi na indukciji. ${ }^{22} \mathrm{U}$ djelu $O$ zakonu neprekinutosti Bošković razlikuje apriorno (tj. pojmovno) dokazivanje neprekinutosti od njezina induktivnog dokazivanja. Prvim se dokazuje mogućnost zakona neprekinutosti, a drugim zbiljsko postojanje neprekinutosti u prirodi. Nije teško razabrati da je apriorno dokazivanje povezano s metafizičkom argumentacijom. Međutim, valja također uvidjeti da je i induktivni dokaz u širem smislu također metafizički, i to barem iz jednoga razloga, koji se iskazuje u tome što mogućnost induktivnog zaključka uključuje apriornost, odnosno vjeru u analogiju i jednostavnost prirode. Dakle, to je čisti metafizički credo.

Treba $\mathrm{k}$ tome istaknuti da najizravnija posljedica bezrezervnoga prihvaćanja zakona kontinuiteta postaje vidljiva u Boškovićevu uvođenju odbojne sile. Naime, posrijedi je sila koja ne dopušta neposredni dodir između dvaju tijela ili dviju čestica: kada međusobni razmak između tijelâ ili česticâ poprimi ekstremno male vrijednosti, tada odbojna sila raste do ekstremno velikih vrijednosti. Bošković pomno analizira sraz (sudar) tijelâ, kao aktualan prijepor u ondašnjoj znanosti, te zaključuje da predodžba krutog atoma stoji u suprotnosti s principom po kojemu se brzine kontinuirano mijenjaju. Da bi spasio načelo neprekinutosti, Bošković uvodi odbojne sile na krajnje malim udaljenostima. O tome kaže:

»Da izbjegne svaki skok, u svakom slučaju morala se priroda osigurati takvom silom koja smanjenjem udaljenosti raste u beskonačnost, i to raste tako da je kadra uništiti svaku brzinu, ma kako ona bila velika. Prema tome došli smo do odbojnih sila koje sa smanjenjem udaljenosti beskonačno rastu, $(\ldots) . \ll^{23}$

Time se dosljedno zabacuje narušavanje neprekinutosti u prirodi i, s druge strane, ruši ne samo jedan od temeljnih aksioma svakidašnjeg iskustva nego i uvriježena uvjerenja među znanstvenicima i filozofima. ${ }^{24}$

Bošković drži da zakon neprekinutosti vrijedi bezuvjetno i beziznimno. Posrijedi je čisto metafizički zahtjev - a samo zbog svoje utemeljenosti u metafizici uopće može biti matematički i fizički - koji kaže da se u prirodi ništa ne događa skokom (nihil in natura per saltum fieri).

Uzimajući zakon neprekinutosti kao polazište uzmogao je Bošković dospjeti do svoje ključne teorijske postavke: njegova odbojna sila na krajnje malim udaljenostima raste do neizmjernosti, sprječavajući time neposredni dodir ne samo u mikrosvijetu među Boškovićevim jednostavnim, nedjeljivim, neproničnim i neprotežnim (bezdimenzijskim) materijalnim točkama (koje su uza sve obdarene, uvjeren je Bošković, i inercijom - što je mnogim fizičarima još i danas teško prihvatiti) nego k tome sprječava dodir i među makroskopskim tijelima. Za rečeno valja spomenuti jedan iskustveni primjer, koji umanjuje 
pouzdanost iskustva posredovanoga varljivim čovjekovim osjetilima: bilijarske se kugle pri srazu zapravo ne dodirnu, njihov dodir nije zbog odbojne sile moguć; a ono što vidimo samo je perceptivna varka posredovana neistančanim čovjekovim osjetilima. Tako tu pojavu, prkoseći osjetilnome iskustvu i dojmu, objašnjava Ruđer Bošković. ${ }^{25}$

Friedrich Nietzsche o tome kaže da je Boškovićeva teorija »najveći trijumf nad osjetilima koji je do sada postignut na Zemlji«. Bošković i Poljak Kopernik »najveći su protivnici pričina«, tvrdi Nietzsche objašnjavajući:

»Dok nas je Kopernik nagovorio da protiv svih osjetila vjerujemo da Zemlja ne stoji čvrsto, Bošković je naučavao kako da se pod zakletvom odreknemo vjere u 'tvar', u 'materiju', u atom ostatka zemlje i atom hrpice. $\ll^{26}$

Do toga izvornog rezultata, vrijedi istaknuti, Bošković dospijeva osobitim spoznajnim postupkom koji označava tradicionalnim skolastičkim nazivom 'ispravno umovanje' ili 'ispravno razmišljanje' (recta ratiocinatio). ${ }^{27}$

Neotklonjivo se nadaje pitanje što je zapravo Boškovićevo 'ispravno razmišljanje' i od čega se ono sastoji. Zasigurno nije riječ o spoznajnom postupku zasnovanome na eksperimentalnim zahvatima kojima bi se proniknulo u ontičku bît pojavnoga svijeta. Jer kada govorimo o mikrofizici, tj. o fizici elementarnih čestica, treba napomenuti da u 18. stoljeću ne može biti riječi o eksperimentalnim zahvatima na kojima bi se temeljili sudovi o mikrostrukturi pojavne zbilje.

Boškovićevo je 'ispravno razmišljanje' spoznajni odnosno metodološki postupak zasnovan na neiskustvenim, prediskustvenim i nadiskustvenim -

je vezana uz priznavanje metafizičke razlike između bitka i spoznaje, tj. prvenstva reda bitka u odnosu na red spoznaje (npr. uzrok u naravnom redu prethodi učinku, premda učinak ima prvenstvo u redu spoznavanja). U skladu s modernim značenjem, a priori je nešto spoznato neovisno od iskustva, dok a posteriori označava neke sadržaje spoznate na temelju iskustva. Usp. Anto Mišić, Rječnik filozofskih pojmova, Verbum, Split 2000., str. 33

18

»Ego, cum in eam primo inquirerem, censui, eandem omitti omnino non posse; si eam, quam habemus unicam, Naturae analogiam, et inductionis vim consulamus $(. .$.$) .«-Ruđer$ Bošković, Teorija prirodne filozofije svedena na jedan jedini zakon sila koje postoje u prirodi (Theoria philosophiae naturalis redacta ad unicam legem virium in natura existentium), dvojezično izdanje, Sveučilišna naklada Liber, Zagreb 1974. (=ThPhN), br. 38; usp. $\operatorname{ThPhN}$, br. 31

19

Usp. S. Kutleša, Prirodnofilozofijski pojmovi Ruđera Boškovića, str. 45-52.

20

Usp. Marito Mihovil Letica, Odnos metafizike $i$ znanosti: Boškovićevo metafizičko prirodoslovlje, Filozofsko-teološki institut Družbe Isusove, Zagreb 2011., str. 135-150.

21

Usp. $T h P h N$, br. 48, 52, 55 .
22

Usp. Ruđer Bošković, $O$ zakonu neprekinutosti (De continuitatis lege), preveo Josip Talanga, dvojezično izdanje, Školska knjiga, Zagreb 1996., br. 5, 135, 137.

23

»Debebit igitur ad omnem pro omni casu evitandum saltum Natura cavisse per ejusmodi vim, quae imminutis distantiis crescat in infinitum, atque ita crescat, ut par sit extinguendae cuincunque velocitati, utcunque magnae. Devenimus igitur ad vires repulsives imminutis distantiis crescentes in infinitum $(. .$.$) .《$ - ThPhN, br. 77, str. 35 24

Usp. Ivan Supek, Filozofija, znanost $i$ humanizam, Hrvatska akademija znanosti i umjetnosti, Školska knjiga, Zagreb 1995., str. 66; usp. S. Kutleša, Prirodnofilozofijski pojmovi Ruđera Boškovića, str. 74-75, 328.

25

Usp. S. Kutleša, Filozofija Ruđera Boškovića str. 11-15.

26

Friedrich Nietzsche, S onu stranu dobra i zla predigra filozofiji budućnosti, prevela Dubravka Kozina, AGM, Zagreb 2002., str. 23. 27

Usp. S. Kutleša, Prirodnofilozofijski pojmovi Ruđera Boškovića, str. 328. Pobliže o skolastičkom pojmu recta ratiocinatio usp. Andre- 
tj. a priori - postavkama (koje se oslanjaju na načelo neprekinutosti te načelo jednostavnosti i sličnoznačnosti prirode), a rečene postavke nisu ništa drugo nego nosive sastavnice njegova metafizički ustrojena misaonog postupka kojim postulira strukturu i zakonitosti osjetilima nedostupne zbilje. Posrijedi je deduktivno strukturirani spoznajni pristup osvijetljen metafizičkom spekulacijom i vođen prodornim prirodoznanstvenim intuicijama.

\section{Boškovićeva dedukcija i indukcija}

Bošković se u svojoj kompleksnoj i nekonvencionalnoj spoznajnoj teoriji služi i dedukcijom i indukcijom. Jedno od polazišta svoje prirodne filozofije - načelo neprekinutosti - potkrepljuje i deduktivno i induktivno. Pravila indukcije stavlja ponajprije u službu nacrta prirode te uviđa da indukcija postaje smislen metodološki postupak samo nakon razumskog uvida i vjere u jednostavnost i analogiju unutar prirode. Bošković primjenom tih pravila dokazuje neproničnost (neprobojnost). ${ }^{28}$ Indukciju stavlja i u službu svoje teorije jedinstvene sile, što nikako ne znači da joj je potreban takav oslonac: ona je dosljedno proveden zaključak iz temeljnih geometrijskih premisa, a pravilo indukcije samo omogućuje da taj nužni zaključak postane lakše provediv. Filozof znanosti i teolog Vjekoslav Bajsić o tome kaže:

»Tu, međutim, indukcija jasno očituje svoje, možemo čak reći prostorne granice te prepušta vodstvo matematičkoj dedukciji. Značajno je za Boškovićevo poimanje fizike što u prirodi nužno postoje područja u koja nije moguće prodrijeti eksperimentom ni pozitivnom indukcijom iz eksperimenta, nego samo dedukcijom. To su neprotežna središta njegove sile, koja je na tim mjestima odbojna do neizmjernosti, tako da neka okolina te točke uvijek ostaje nedostupna eksperimentalnim zahvatima. ${ }^{29}$

Postavi li se zahtjev razumijevanja i tumačenja nekoga prirodnog predmeta, rastavit ćemo ga na dijelove koje smatramo jednostavnijima od cjeline. Dijelovi u odnosu na cjelinu moraju biti različiti i raznorodni. U suprotnom se ništa ne bi moglo protumačiti; jer bi zagonetka cjeline ostala u njezinim dijelovima. Stoga, želimo li izbjeći zamku tautologije i novim uvidima protumačiti fizička bića, dijelovi tih bića moraju imati posve različita svojstva od onih što ih našim osjetilima zamjećujemo na cjelini. Budući da ta svojstva nisu osjetilno dostupna, moguće ih je oslikati samo svojevrsnim misaonim eksperimentom. Ako Ruđer Bošković iz neiskustveno neprotežnoga tvori iskustveno protežno, to s obzirom na prije izneseno ima posve logično utemeljenje, a sa sličnim se problemima često suočava i hvata u koštac moderna fizika, napose kvantna teorija. ${ }^{30}$

Iz prethodnoga možemo uvidjeti da je Boškovićeva temeljna spoznajna metoda dedukcija koja ga usmjerava i vodi od općega epistemološkog polazišta prema prirodoznanstvenom principu, a od njega dalje do tumačenja pojedinih prirodnih pojava. To je osnovni način Boškovićeva traganja za prirodnim zakonima. ${ }^{31}$ Pritom je veoma važan njegov deduktivni lanac koji čine sljedeće karike: analogija i jednostavnost prirode, kritičko stajalište prema eksperimentima i sposobnosti osjetila, razlikovanje matematičkog od fizičkog dodira te princip neprekinutosti u prirodi. Iz potonjega proizlazi da se u prirodi ništa ne događa skokovito, priroda ne čini skokove. Riječ je o osobitu epistemološkom pristupu slijedom kojega je princip neprekinutosti deduciran iz općenitije postavke, analogije i jednostavnosti prirode, a dotični princip zahtijeva da se bilo koja promjena određene veličine, bilo da je riječ o povećanju ili umanjenju, odvija uvijek neprekinutim gibanjem kroz sve međuveličine. Takav zakon neprekinutosti nužno podrazumijeva i isključenje matematičkoga 
dodira, tj. dodira 'u kojem ne postoji interval po sebi'. Matematički ili neposredni dodir (u kojemu ne bi bilo međusobne razdvojenosti, udaljenosti) onemogućio bi opisivanje fizičkih događaja jedinstvenom silom jer bi matematički dodir, s obzirom na funkcijsku ovisnost veličine sile o udaljenosti, podrazumijevao prekide i skokovite promjene. Zato Bošković dopušta samo fizički dodir, koji nastupa približavanjem dvaju tijela na toliko malu udaljenost da je osjetilima nezamjetljiva; a tada odbojna sila raste do neizmjernosti. Pri tome se Bošković služi svojim ‘ispravnim razmišljanjem' u zaključivanju da se struktura tvari ima sastojati od jednostavnih, neprotežnih i nedjeljivih točaka jer bi jedino takve izbjegle rasprsnuće uslijed djelovanja neizmjerno jake odbojne sile na neizmjerno malim udaljenostima. Bošković zapravo zahtijeva infinitezimalno male točke kao sveprožimajuće ustrojstvo stvarnosti, odnosno neprotežne točke koje se sadržajno prebacuju iz materije u energiju i time na teško pojmljiv način pomiruju ništavilo i beskonačnost. Ovdje treba istaknuti da je Bošković glede pitanja o beskonačnosti vjeran Aristotelu i aristotelovsko-skolastičkoj tradiciji: dopušta samo potencijalnu ili matematičku beskonačnost, dok smatra da aktualnoj beskonačnosti nema mjesta u aktualnome, ozbiljenome svijetu, odnosno svemiru. ${ }^{32}$

\section{Bošković i teorija relativnosti}

Uvelike nadilazeći vlastito okružje i povijesni trenutak, Bošković nudi bitno drukčije shvaćanje tvari, prostora i vremena u usporedbi s mnogim svojim uglednim onodobnicima. S druge strane on, nasuprot prosvjetiteljskom utopijskom zahtjevu da čovjek pronikne u sve tajne i zadobije posvemašnje znanje, umije procijeniti mogućnosti i ograničenja ljudske spoznaje. Svakako je zanimljivo i vrijedno isticanja da Bošković u svojim metafizičkim razmatranjima o prostoru i vremenu - a prema njegovu dubokom uvjerenju drukčija ne mogu ni biti - polazi poput sv. Augustina od metodičke skepse. Boškovićeva aluzija na Augustinovu misao više je nego bjelodana:

»Uostalom ustroji vremena i prostora odnose se na metafiziku i takvi su da znamo što su kad nitko ne pita, a gotovo ne znamo kad tkogod pita.«33

as Jaszlinszky, Institutiones logicae, in usum discipulorum concinnatae, Typis Academicis Societatis Jesu, Trnava 1755., br. 190.

28

Usp. S. Kutleša, Prirodnofilozofijski pojmovi Ruđera Boškovića, str. 181-186.

29

Vjekoslav Bajsić, »Pojam i značenje Boškovićeva principa indukcije«, u: Valentin Pozaić (ur.), Filozofija znanosti Ruđera Boškovića, Filozofsko-teološki institut Družbe Isusove, Zagreb 1987., str. 55.

30

Ibid.

31

Usp. Ivica Martinović, »Temeljna dedukcija Boškovićeve filozofije prirode«, u: V. Pozaić (ur.), Filozofija znanosti Ruđera Boškovića, str. 58-62.
32

O različitim vrstama beskonačnosti usp. Vladimir Devidé, »Potencijalna i aktualna beskonačnost«, u: Zlatko Šporer (ur.), Razgovori o matematici, Školska knjiga, Zagreb 1973. str. 313-314.

33

»Ceterum temporis, et spatii constitutio ad metaphysicam pertinent, et ejusmodi sunt, ut ea, nemine interrogante, quid sint, sciamus, interrogante aliquo fere ignoremus.« - Ruđer Bošković, »De materiae divisibilitate et principiis corporum $\ll[\gg \mathrm{O}$ djeljivosti tvari i počelima tijela«], Memorie sopra la Fisica e Istoria naturali di diversi Valentuomini, tomus IV, Lucca 1757. Prijevod preuzet iz: S. Kutleša, Prirodnofilozofijski pojmovi Ruđera Boškovića, str. 266. 
Tvrdnjom da neposrednim opažanjem nije moguće razlikovati apsolutni od relativnoga prostora, zatim obrazloženim zagovaranjem ideje o promjenama dimenzijâ tijelâ njihovim premještanjem, Bošković zavrjeđuje biti smatran prethodnikom teorije relativnosti. $\mathrm{K}$ tome se u njegovim idejama mogu pronaći vrlo uvjerljiva naslućivanja četvrte dimenzije prostora. Neovisno o tome vrednovala se ta relativnost samo u spoznajnom smislu, ${ }^{34}$ ili pak u smislu onoga što se u 20. stoljeću pod teorijom relativnosti uobičajeno shvaćalo, a potonja mogućnost podrazumijeva mišljenje da se moderne relativističke koncepcije razumijevaju samo kao reprodukcije pojmova o kojima je Bošković davno prije raspravljao - njegova je uloga na ovome području znanosti krčiteljska i neosporna, a mjesto što ga je time zavrijedio u svakom je slučaju istaknuto i povlašteno. ${ }^{35}$

Početkom teorije relativnosti službeno se smatra godina 1905. kad Albert Einstein ozbiljno uzdrmava uvriježenu sliku stvarnosti, predodžbu kojoj je već u 19. stoljeću klasična njutonovska prirodna filozofija (njutonovska fizika) zbog sve očitijih proturječja i neprikladnosti oduzimala sveobuhvatnost a time naposljetku i zahtijevanu istinitost. Premda bi se početkom života moderne fizike s pravom mogla smatrati i godina 1900. kada Max Planck objelodanjuje svoju kvantnu teoriju - za početak moderne fizike i cjelokupne moderne znanosti gotovo se uobičajeno uzima 1905. godina, odnosno početak teorije relativnosti. Ona je znanstvenu zajednicu, a i širu javnost, prisilila mijenjati uvjerenja koja su bila podupirana čitavim unutarsvjetskim iskustvom još od početka znanstvene (tj. fillozofske) misli u staroj Grčkoj. Prostor početkom 20. stoljeća prestaje biti poiman samostalnim i neovisnim bićem koje materiju rigorozno podvrgava vlastitoj strukturi; a pojam vremena s postulatom konstantne i neprekoračive brzine svjetlosti time dobiva posve novo semantičko polje.

Teorijom relativnosti utvrđeno je da se geometrijski pojmovi ozbiljuju samo prilikom njihove primjene na realna tijela. Einstein smatra da je takva nadopunjena geometrija zapravo najstarija grana fizike i da tek iskustvo može pokazati njezinu strukturu: tradicionalnu euklidsku ili pak neku novu. Nadalje, važno je primijetiti da Einstein dokidanjem apsolutnoga prostorno-vremenskog okvira postuliranog u Kantovoj filozofiji osporava univerzalnu vrijednost tim oblicima opažanja što 'svako iskustvo čine mogućim'. ${ }^{36}$

U Einsteinovoj ideji o mogućnosti realizacije geometrijskih pojmova tek njihovom primjenom na postojeća tijela nije teško razaznati Boškovićevo stajalište da od matematičkoga prostora, što ga razmatra geometrija, valja razlikovati fizički prostor koji je realan i ne može postojati bez objekata. Iz toga nadalje bjelodano proishodi da znanost 20. stoljeća zabacuje Kantovo idealno i potvrđuje Boškovićevo realno shvaćanje prostora i vremena. Bošković uvjerenje da su prostor i vrijeme 'stvarni načini postojanja' (modi reales existendi) opravdava objašnjenjem sadržaja koji pripisuje tomu pojmu:

»Prema tome nužno se mora prihvatiti neki stvaran način postojanja po kojem se stvar nalazi tamo gdje jest i tada kada jest. Bilo da taj način nazovemo stvar ili način stvari ili nešto što nije ništa, on mora biti izvan naše imaginacije i stvar ga može mijenjati tako da čas ima jedan, čas drugi takav način postojanja. Ja dakle sve pojedine točke materije s obzirom na to kako ja o njima govorim - a to se sve vrlo lako može prenijeti i na nematerijalne stvari - tvrdim da postoje dvije stvarne vrste njihova načina postojanja, od kojih se jedni odnose na mjesto, a drugi na vrijeme. (...) Po mom su mišljenju ti stvarni načini stvarno vrijeme i prostor. Mogućnost tih načina, koju mi neodređeno spoznajemo, jest po mom mišljenju prostorni vakuum i, da tako kažem, vremenski vakuum ili pak imaginarni prostor i imaginarno vrijeme. $\ll^{37}$

Prema Kantovu mišljenju moguće je zamisliti čisti prostor i vrijeme koji su ispražnjeni od tijela, ali nije moguće zamisliti tijela bez prostora. Prostor je 
shvaćen kao uvjet mogućnosti pojava, a ne kao način postojanja koji je pojavama određen. ${ }^{38}$ Važno je $\mathrm{k}$ tomu spomenuti da se Kant posve oslanja na prostorno-vremenski okvir Isaaca Newtona, s bitnom razlikom što je njegovu objektivnost zamijenio imanentističkim utemeljenjem. Kant se otklanja od aristotelovsko-skolastičkih kategorija: kategorije koje je uspostavio ne označavaju najviše načine bitka, nego apriorne forme čovjekova spoznavanja. Posebno zanimljivom iskazuje se svojevrsna konfesionalno-epistemološka komparacija u zapažanju fizičara i filozofa Ivana Supeka:

»Ako katolik Bošković i protestant Kant uzimaju transcendentalno izvorište, njihove su postavke ipak bitno različite. Transcendentalno je za Ruđera jamstvo spoznaje, za Kanta pak razlog agnosticizma. $« 39$

Supekovo je zapažanje umjesno, poglavito s obzirom na epistemološki dio. Možemo reći da Bošković upravo zbog otvorenoga prihvaćanja transcendentalnog nije metafiziku smatrao bremenom, nego istinskim darom i zadatkom. U skladu s time Bošković razborito odlučuje ne odbaciti u potpunosti Newtonove pojmove apsolutnoga prostora i vremena, nego ih nastoji predočiti na novi i znatno obuhvatniji način; ukazujući pritom na velike poteškoće koje proizlaze iz Newtonova razlikovanja apsolutnoga prostora i apsolutnoga vremena od relativnoga prostora i vremena, a time i apsolutnoga od relativnoga gibanja. Te probleme Bošković nastoji razriješiti uvođenjem 'dvoslojnoga prostora', posežući za aristotelovsko-skolastičkim pojmovnim parom potencijalno - aktualno.

Naime, Boškovićev relativni prostor, koji je zbiljski (fizički) i sadrži sve stvari te je ujedno referencijski sustav za njihovo gibanje, preuzima ulogu Newtonova apsolutnoga prostora; dok je apsolutni prostor u Boškovićevu smislu samo moguć (potencijalan) jer pretpostavlja beskonačnost. ${ }^{40}$ Osim što je Boškovićev apsolutni prostor beskonačan i potencijalan, on je i matematički (geometrijski), neprekinut (kontinuiran) i zamišljen (imaginaran, virtualan). $\mathrm{K}$ tome je potrebno razjasniti da se potencijalnost kod Boškovića ne bi smjela razumijevati samo kao 'mogućnost bivstvovanja' nego također i prije svega kao ‘bivstvovanje mogućnosti'. U takvoj Boškovićevoj koncepciji potencijalnost zadobiva znatno veću ontološku puninu i snagu.

34

Usp. Arcangelo Rossi, »Boškovićeva filozofija prostora«, Filozofska istraživanja 9 (1989) 5-6, str. 1597-1603, str. 1600.

35

Usp. M. M. Letica, Odnos metafizike $i$ znanosti, str. 151-162.

36

Usp. I. Supek, Filozofija, znanost $i$ humanizam, str. 87.

37

»Necessario igitur admittendus est realis aliquis existendi modus, per quem res est ibi, ubi est, et tum, cum est. Sive is modus dicatur res, sive modus rei, sive aliquid, sive nonnihil; is extra nostram imaginationem esse debet, et res ipsum mutare potest, habens jam alium ejusmodi existendi modum, jam alium. Ego igitur pro singulis materiae punctis, ut de his loquar, e quibus ad res etiam immate- riales eadem omnia facile transferri possunt, admitto bina realia modorum existendi genera. (...) Hic reales existendi modi sunt mihi reale tempus, et spatium: horum possibilitas a nobis indefinite cognita est mihi spatium vacuum, et tempus itidem, ut ita dicam, vacuum, sive etiam spatium imaginarium, et tempus imaginarium. « - ThPhN, »Dopuna $\mathrm{I} \ll$ (»Supplementum $\mathrm{I} \ll$ ), br. 3-4.

38

Usp. Ivan Supek, Ruđer Bošković: vizionar $u$ prijelomima filozofije, znanosti $i$ društva, Školska knjiga, Zagreb 2005., str. 87.

39

Ibid., str. 90

40

Usp. Zvonimir Čuljak, Nastanak Boškovićeve filozofije prostora $i$ vremena, Hrvatsko filozofsko društvo, Zagreb 1992., str. 89-96. 
Ivan Supek primjećuje da je Bošković dihotomijom potencijalno - aktualno, odnosno svojom dvoslojnošću prostora, »nadišao čisto objektivističko shvaćanje i približio se jedinstvu subjektivnog i objektivnog «. $^{41}$ Bošković smatra da ono što potencijalnost prevodi u aktualnost jest upravo sila, a nju shvaća dvoslojno, kao potencijalnu i aktualnu ili djelatnu (vis potentia - vis activa). Ta aristotelovsko-skolastički shvaćena dvoslojnost sile ima, uz ostalo, presudnu važnost kod tumačenja gibanjâ u mikrosvijetu. ${ }^{42}$

Aristotelovsko-skolastička analogija bitka, odnosno učenje o mogućnosti i zbiljnosti (potentia et actus) neizbježna je također i u Boškovićevu tumačenju diskretnosti fizičkoga (zbiljskog, relativnog) i kontinuiranosti matematičkoga (mogućeg, apsolutnog) prostora. Stipe Kutleša objašnjava:

»Bošković smatra da se o apsolutnom ili mogućem prostoru ne može ništa znati. Međutim, prema njegovu mišljenju ne može se spoznati ni relativni ili zbiljski prostor kakav je po sebi. Isto vrijedi i za vrijeme. Nama je dopušteno spoznati prostor i vrijeme samo onako kako nam se prikazuju, kakvi su nam predočeni. To je stoga što su zbiljski prostor i vrijeme rezultat zbiljskih načina postojanja materijalnih točaka, a ovi se načini postojanja neprestano mijenjaju. Našem spoznajnom ustroju nije dano spoznati promjene u svijetu koje su posljedice tih promjena. Zato nam nespoznatljive ostaju, između ostalog, i prije spomenute promjene dimenzijâ tijelâ njihovim pomicanjem u prostoru i vremenu. Upravo iz navedenog proizlazi za našu spoznaju relativnost prostora i vremena. $\ll^{43}$

Boškovićev otklon od Newtonova učenja i približavanje kasnijim relativističkim koncepcijama Ernsta Macha i Alberta Einsteina objašnjava Kutleša sljedećim rečenicama:

»Newtonov apsolutni prostor je sveobuhvatni koordinatni sustav Euklidove geometrije. K tome su postojali i metafizičko-teološki motivi za uvođenje apsolutnog prostora. Newton je dokazivao da je apsolutni prostor jedno od svojstava samog Boga. Prostor je stoga ono biće koje je vječno, beskonačno, savršeno i nepromjenjivo; on je kao i Bog sveprisutan. (...) Fizički se svijet u tom smislu naziva tijelo Božje. Dokaze za postojanje apsolutnoga prostora Newton je dokazivao dvama pokusima: rotirajućom posudom s vodom i pomoću dvije kugle koje rotiraju okolo zajedničkog težišta. Te su dokaze kritizirali Bošković i Mach dokazujući njihovu neispravnost. Ipak se ideja o apsolutnosti prostora zadržala sve dok nije došlo do drukčijih predodžbi koje su se pojavile otkrićima neeuklidskih geometrija i prostora drukčijih od euklidskog. Potpuno razbijanje predodžbe o apsolutnosti prostora dolazi s teorijom relativnosti. «4

Osvrnemo li se na kronološku i biografsku činjenicu da je fizičar i filozof Ernst Mach rođen pola stoljeća nakon završetka Boškovićeva života, i ovdje postaje očitim prvenstvo hrvatskoga znanstvenika. Treba doduše reći da su apsolutnost Newtonova prostora kritizirali već George Berkeley i G. W. Leibniz, čime je potonji prema Machovu mišljenju prethodio poimanju relativnosti gibanja. Međutim, valja ispravno vrednovati činjenicu da Leibniz nije prihvaćao dvojstvo prostora. Kod njega nema odnosnosti između stvarnoga (u Boškovićevoj terminologiji relativnoga) i matematičkoga (Boškovićeva apsolutnoga) prostora, a upravo je isticanje odnosâ između tih dvaju prostora važno za približavanje teoriji relativnosti. ${ }^{45}$

Bošković ističe da ono što vrijedi za prostor - mijenjanje udaljenosti između točaka materije kada se tijela premještaju - analogno vrijedi i za vrijeme:

»Ono što rekosmo o mjeri prostora nije baš teško prenijeti na vrijeme, u kojem isto tako nemamo nikakvu određenu i stalnu mjeru. Mi je izvodimo iz gibanja, koliko možemo, ali nemamo gibanje koje bi bilo potpuno jednoliko. (...) U pogledu mjere vremena ni običan puk ne smatra da se od jednog vremena k drugom može prenijeti ista mjera vremena. Vidi on da je to druga mjera, ali je smatra jednakom zbog pretpostavljenog jednolikog gibanja. Kao što je to s mjerenjem vremena, tako je za moju teoriju u pogledu mjerenja prostora nemoguće prenositi određenu duljinu, kao tamo trajanje, sa svog mjesta na drugo mjesto da bismo mogli usporediti dvije stvari pomoću treće. U jednom i drugom slučaju neka druga duljina ili neko drugo trajanje zamjenjuje 
se s onim što se smatra jednakim onom prvom, $\mathrm{tj}$. nova stvarna mjesta točaka iste desetostopne šipke sačinjavaju novu udaljenost, kao što je nova kružnica učinjena istom pisaljkom, odnosno nova vremenska udaljenost između dva početka i dva kraja. U mojoj teoriji postoji u svakom slučaju ista analogija između prostora i vremena. « ${ }^{46}$

Iz navedenih Boškovićevih razmatranja proizlazi da nije moguce neposredno spoznati apsolutne vremenske razmake niti se oni mogu uspoređivati s nekim mjerilom koje bi bilo zajedničko i stalno. Drukčije kazano, kao što svaki sustav (dio prostora) ima svoje udaljenosti među česticama, tako ima i svoje intervale među događajima. Bošković se time približio pojmovima koji će kasnije unutar teorije relativnosti dobiti atribute 'relativnih prostornih dimenzija mjesnoga (lokalnoga) vremena', čime je izrečena smiona tvrdnja da svaki sustav ima svoje vlastite vrijeme i prostor. ${ }^{47}$

Međutim, želimo li dospjeti do nepristranoga i vjerodostojnoga stajališta o značaju Boškovićevih doprinosa teoriji relativnosti, valja uvidjeti i priznati da razlike između Boškovića i Einsteina ipak postoje te da one u nekim pojedinostima nisu beznačajne. Naznačit ću ih ukratko u sljedećim rečenicama. Naime, dok razvijena teorija relativnosti posve odbacuje apsolutno vrijeme kao nešto zbiljsko, Bošković nije sklon takvu odbacivanju apsolutnoga prostora i vremena, nego se zadržava na nepriznavanju njihove apsolutne spoznatljivosti. Zatim Bošković ostaje nedorečen u govoru o vrsti promjene mjere vremena prilikom prenošenja te mjere iz jednoga vremena u drugo: ne kaže produljuje li se ili skraćuje jedinica vremena kod njezina prenošenja između različitih vremenâ. K tome valja reći da Bošković ne dovodi promjenu vremena u funkcijski odnos s brzinom (brzinu svjetlosti nije ni pokušao uklopiti u ovaj kompleks problemâ); štoviše, bilo kakvu brzinu pri tomu izričito ni ne spominje. ${ }^{48}$

U nekim je drugim pojedinostima Boškovićevo približavanje teoriji relativnosti nešto izričitije ili čak posve izričito. Na kraju djela De maris aestu Bošković zaključuje da cjelokupni problem prostora valja smatrati predmetom jednoga 'metafizičkog ispitivanja'. ${ }^{49}$

I. Supek, Filozofija, znanost i humanizam, str. 84.

42

Usp. S. Kutleša, Prirodnofilozofijski pojmovi Ruđera Boškovića, str. 325-326.

43

Ibid.

44

Ibid., str. 263, 317-323.

45

Usp. I. Supek, Ruđer Bošković, str. 65-66.

46

»Quae de spatii mensura diximus, haud difficulter ad tempus transferentur, in quo itidem nullam habemus certam, et constantem mensuram. Desumimus a motu illam, quam possumus, sed nullum habemus motum prorsus aequabilem. (...) In mensura temporis, ne vulgus quidem censere ab uno tempore ad aliud tempus eandem temporis mensuram transferri. Videt aliam esse, sed aequalem supponit ob motum suppositum aequalem.
In mensura locali aeque in mea sententia, ac in mensura temporaria impossibile est certam longitudinem, ut certam durationem e sua sede abducere in alterius sedem, ut binorum comparatio habeatur per tertium. Utrobique alia longitudo, ut alia duratio substituitur, quae priori illi aequalis censetur, nimirum nova realia punctorum ejusdem decempedae loca novam distantiam constituentia, ut novus ejusdem styli circuitus, sive nova temporaria distantia inter bina initia, et binos fines. In mea Theoria eadem prorsus utrobique habetur analogia spatii, et temporis. «-ThPhN, »Dopuna II $«(»$ Supplementum II $\ll)$, br. 24.

47

Usp. S. Kutleša, Prirodnofilozofijski pojmovi Ruđera Boškovića, str. 311.

48

Ibid.

49

Usp. Ruđer Bošković, De maris aestu (O plimi i oseci mora), Typographia Komarek, Romae 1747. (=MaAe) br. 94 
Ne podliježe sumnji da se Bošković - uzmemo li u obzir vrijeme njegova života i s time povezana znanstveno-tehnička ograničenja - rečenim stajalištima pozicionirao kao punokrvni prethodnik teorije relativnosti. Filozof Zvonimir Čuljak u tome smislu kaže:

»Boškovićeva je filozofija prostora i vremena prvenstveno quaestio metaphysica, teorija koja je sama konstruirala entitete (puncta materiae) na koje se odnose prostorno-vremenske odredbe. Stoga se o Boškovićevu 'relativizmu' može govoriti tek kao o elementu njegove teorije koji nema potporu u matematičkom izrazu niti u - za samoga Boškovića načelno nemogućoj - eksperimentalnoj potvrdi. $\ll^{50}$

Rezimirajmo: stajališta o nemogućnosti razlikovanja apsolutnoga od relativnoga prostora dovode Boškovića do zamisli o nejedinstvenosti prostorne metrike i dalje, preko slutnje neeuklidskih geometrija i relativistički koncipiranoga prostora i vremena, do ideje prostora s četiri dimenzije; što je u svakom slučaju vrlo blisko osobitostima prostornovremenske geometrije u četverodimenzionalnom kontinuumu Hermana Minkovskoga.

Werner Heisenberg, dobitnik Nobelove nagrade za fiziku, više je puta pohvalio oštroumni način Boškovićeve zaokupljenosti prirodnom filozofijom te njegov snažni i gotovo sveprisutni utjecaj na modernu fiziku. Neotklonjivost Boškovićevih ideja u modernoj fizici izriče Heisenberg 1958. godine (o dvjestotoj obljetnici objavljivanja Boškovićeve Teorije prirodne filozofije) ovim gotovo panegiričkim rečenicama:

»Među prirodoslovcima 18. stoljeća zauzima teolog, filozof, matematičar i astronom Ruđer Bošković osobito mjesto. U njegovom glavnom djelu Theoria Philosophiae naturalis (...) nalaze se različiti misaoni sljedovi koji su tek u modernoj fizici posljednjih 50 godina došli do svojeg punog prava, a pokazuje se kako su ispravni bili filozofski nazori koji su vodili Boškovića u njegovoj znanosti o prirodi (...). Pojam polja sile, koji je igrao tako odlučnu ulogu u razvoju fizike 19. stoljeća i poslije, nalazi se već u Boškovića i njime je oplodio kasnije temeljne radove, osobito Faradayeve (...). Kad se temeljna filozofska teza Boškovićeva djela želi izraziti modernim jezikom, tada se može reći da je Bošković smatrao prirodni zakon koji određuje sile između elementarnih čestica ključem za razumijevanje strukture materije. A tim shvaćanjem stoji on izvanredno blizu našem današnjem nazoru. $\ll^{51}$

Zatim, Niels Bohr, također dobitnik Nobelove nagrade iz područja fizike, za Boškovića pouzdano kaže:

»On nije samo dao važan doprinos matematici i astronomiji, nego je nastojao, znatnom imaginacijom i logičkom snagom, razviti sustavni prikaz svojstava na temelju interakcije mase točaka pomoću središnjih sila. U tom pogledu Boškovićeve su ideje vrlo duboko utjecale na rad sljedećih generacija fizičara $(\ldots) \ll{ }^{52}$

O Faradayu i Maxwellu, odnosno o njihovim zaslugama za uvođenje polja također piše fizičar i kozmolog Stephen Hawking u knjizi Velebni plan:

»Jedan od Faradayevih najvećih intelektualnih dosega bijaše dobra zamisao polja sile. Ovih dana, zahvaljujući knjigama i filmovima o buljookim svemircima i njihovim interstelarnim brodovima, većina ljudi se upoznala s tim pojmom, no Faradayu bi trebali pripasti tantijemi od autorskih prava. Ali tijekom stoljeća između Newtona i Faradaya, jedna od najvećih zagonetki fizike bila je da njeni zakoni, čini se, ukazuju da sile između predmeta djeluju kroz prazan prostor koji ih razdvaja. (...) Danas smatramo da se sve sile prenose putem polja, stoga je to važan pojam u suvremenoj fizici - i u znanstvenoj fantastici. (...) Danas se jednadžbe koje opisuju električna i magnetska polja zovu Maxwellove jednadžbe. Malo je ljudi čulo za njih, no to su za gospodarstvo vjerojatno najvažnije jednadžbe koje znamo. Ne samo da one vladaju funkcioniranjem svih električnih aparata, od kućanske bijele tehnike do računala, već i opisuju valove koji nisu vidljiva svjetlost, na primjer mikrovalove, radiovalove, infracrvene (toplinske) valove i rendgenske zrake. $\aleph^{53}$

Nakon navedenoga poželjno je predočiti kako su stajališta o korijenima svojih znanstvenih poticaja presudnih za uvođenje polja izrekli Faraday i Maxwell. 
Boškovićeva zamisao da jednostavne i neprotežne točke bivaju središtima sila koje se djelovanjem protežu u okolni prostor tako da zapravo ne postoji praznina, nego polje sila - pokazala se osobito plodonosnom u radovima ove dvojice znanstvenika. Faraday bez ustručavanja priznaje da je poimanje polja preuzeo od Boškovića. ${ }^{54}$ (I vjerojatno bi se kao dobar engleski džentlmen odrekao tantijema od autorskih prava za filmove znanstvenofantastičnog žanra, ili bi ih u najmanju ruku bio spreman podijeliti s jezuitskim patrom Boškovićem.) A Maxwell u zapisima Lectures on Faraday's lines of Force ističe Boškovićevu teoriju prema kojoj su tijela sastavljena od matematičkih točaka obdarenih silom inercije. ${ }^{55} \mathrm{Na}$ istom tragu kao Faraday, i Maxwell uvjereno tvrdi:

»Najbolje je, što možemo učiniti, da se oslobodimo krute jezgre i zamijenimo je Boškovićevim atomom. $\ll^{56}$

Njihova naučavanja o točkastim središtima koje zrače silnice u prostor, samo je razrađena i nadograđena Boškovićeva na metafizičkoj spekulaciji zasnovana teorija.

\section{Bošković i kvantna teorija}

Razvitak znanosti 20. stoljeća više nije zahtijevao takvu izravnu zaokupljenost Boškovićevom teorijom kao što to je to bio slučaj sa znanošću 19. stoljeća. Ipak se u drugoj polovici 20. stoljeća još uvijek osjećaju prednosti znanstvenih rješenja nadahnutih Boškovićevim idejama. Ponekad se to zbiva nesvjesno, ponekad svjesno, a nerijetko znanstvenicima tek naknadno bude jasno da su njihova otkrića i teorije posve u duhu Boškovićevih razmatranja o određenome prirodoznanstvenom području. ${ }^{57}$ To se posebice odnosi na one tijekove moderne znanosti koji se odvijaju u teorijskom i eksperimentalnom ambijentu obuhvatnoga pojma kvantne fizike; a ta obuhvatnost, kao što ćemo vidjeti, izlazi iz okvira onoga što se danas pod fizikom, čak i među mnogim fizičarima, gotovo uvriježeno razumijeva. ${ }^{58}$

Protežnost, kako je Bošković zamišlja, nije sačinjena od materijalnih točaka uzetih zasebno, niti je sastavljena od praznoga prostora. Također nije sastav-

50

Z. Čuljak, Nastanak Boškovićeve filozofije prostora $i$ vremena, str. 218.

51

Werner Heisenberg, »Ruđer Bošković«, Actes du Symposium international R. J. Bošković 1958, Beograd, Zagreb, Ljubljana 1959., str. 29.

52

Niels Bohr, »R. J. Bošković«, Actes du Symposium international R. J. Bošković 1958, Beograd, Zagreb, Ljubljana 1959., str. 27.

53

Stephen Hawking, Leonard Mlodinow, Velebni plan, preveo Damir Mikuličić, Izvori, Zagreb 2010., str. 102.

54

Usp. Stanko Hondl, »Faraday o Boškovićevoj atomistici«, Nastavni vjesnik 9-10 (19311932) 40, str. 257-266.
55

Usp. Peter M. Harman, The Scientific Letters and Papers of James Clerk Maxwell, sv. II, Cambridge University Press, Cambridge 1995., str. 799, 812.

56

Citirano prema: I. Supek, Filozofija, znanost $i$ humanizam, str. 67; usp. Žarko Dadić, Ruđer Bošković, Školska knjiga, Zagreb 1998., str. 118-119.

57

Usp. Ž. Dadić, Ruđer Bošković, str. 125.

58

Usp. M. M. Letica, Odnos metafizike i znanosti, str. 163-197. 
ljena ni od materijalnih točaka i praznoga prostora koji su uzeti zajedno - protežnost se naime sastoji od međusobno razdvojenih materijalnih točaka koje su nepronične zahvaljujući djelovanju Boškovićeve sile. Dakle, protežnost proizlazi iz neproničnosti točaka, a pri tome je riječ o 'novoj' protežnosti koja je prema Boškovićevu mišljenju samo prividna i ne može biti neprekinuta u matematičkom smislu, nego samo u fizičkom. ${ }^{59}$

Rečena Boškovićeva stajališta bila su teško shvatljiva čak i njegovim najučenijim i najupućenijim suvremenicima. Naime, ako Bošković dopušta samo fizički dodir, tj. fizički kontinuitet i fizičku protežnost, a oni su samo prividni - to zapravo znači da on ne dopušta nikakav dodir u prirodi, premda se pojam 'fizički' na prirodu izravno odnosi. To proizlazi iz okolnosti da čovjek svojim osjetilima ne može prodrijeti u svijet mikrofizike, nego mu osjetila omogućuju dohvaćanje samo makroskopskih objekata, tj. njihovih manifestacija dostupnih čovjekovim osjetilima.

Do osobitoga zavaravanja dolazi kada zbog podataka dobivenih posredovanjem osjetilâ vida i dodira zamišljamo tijela neprekinutima. Tako postaje prijeporna i spoznaja sitnih, osjetilima nedostupnih čestica. Bošković upozorava:

»Poznata je praksa kod ljudi, što je čest uzrok isto velikih predrasuda, da smatramo apsolutno kao ništa ono što našim osjetilima ne predstavlja ništa. «00

Poteškoću odnosa protežne cjeline prema svojim neprotežnim (bezdimenzijskim) dijelovima Bošković rješava zamišljajući matematički ili potencijalni prostor kontinuiranim, a čestice kao neprotežne točke dijelovima fizičkoga ili aktualnoga prostora koji je diskontinuiran (diskretan). Tako uspješno pomiruje filozofski zahtjev za načelom kontinuiranosti s aktualnom fizičkom diskontinuiranošću. On pritom odbacuje neprekinutost materije i prihvaća jedino neprekinutost (kontinuitet) unutar prirode kada je riječ o gibanju. ${ }^{61}$ Jasno je međutim da svako gibanje nastaje uslijed djelovanja neke sile.

Dakle, sile u ambijentu prirode osiguravaju neprekinutost. Međutim, sile ujedno uzrokuju prekinutost (diskontinuitet, diskretnost) između točaka materije; a materija je (treba li to uopće isticati?) također dio prirode. Pojednostavljeno kazano: Boškovićev 'jedan jedini zakon sila koje postoje u prirodi' doprinosi istodobnoj neprekinutosti i prekinutosti unutar jedne te iste prirode.

Da bismo uzmogli vjerodostojno nadvladati divergentne problemske tijekove, potrebno se vratiti na već spomenutu ključnu razliku između Boškovićeva poimanja sile u odnosu na Newtonovo i Leibnizovo. Valja jasno istaknuti da Boškovićeva teorija nije dinamička, nego 'dinamistička'. Neprotežne točke unutar ove teorije nisu samo obdarene silama nego se od sila te točke sastoje. Shodno tomu je i Boškovićeva protežnost 'dinamistička'; privid fizičkoga kontinuiteta proizlazi upravo iz činjenice da je materija sačinjena od poljâ ispunjenih silom. ${ }^{62} \mathrm{U}$ takvom viđenju rasplinjuje se uvriježena opreka između materije i energije. Zaista se zadivljujućom iskazuje okolnost da je jedan mislilac u 18. stoljeću bio toliko dalekovid i smion usudivši se takvo što postulirati, i na krilima metafizičkoga mišljenja dospjeti do lucidnoga objašnjenja odnosa neprotežnih dijelova prema protežnoj cjelini koju ti dijelovi čine.

Možemo primijetiti da moderna fizika i u tome pogledu stoji na Boškovićevim pozicijama: njezine teorije naučavaju da se materija sastoji gotovo u potpunosti od praznoga prostora. Udarimo li primjerice čekićem o nakovanj, bit će to sudar dvaju praznih prostora ili, preciznije kazano, dvaju elektromagnetskih polja - samo jake atomske i molekularne sile daju čekiću i nakovnju privid krutosti i ispunjenosti materijom. ${ }^{63}$ 
Kada je riječ o materiji, uputno je podsjetiti da je marksistička filozofija dijalektičkoga materijalizma u nama bliskome 20. stoljeću, filozofija koja se prožela borbenim ateizmom, proglasila materiju jedinom pravom stvarnošću i službenim svjetonazorom - a da je pritom problem materije ostao najteži i najzagonetniji problem u znanosti toga razdoblja. ${ }^{64}$ Definicija materije uvelike ovisi o tome kojoj filozofiji, odnosno kojemu svjetonazoru, pripada onaj tko materiju definira. Možda se jedina općeprihvatljiva definicija iskazuje vrlo apstraktnom i neodređenom:

»Materija je ono što zadovoljava fizikalne zakone. $\ll^{65}$

S obzirom na Boškovićev pokušaj svođenja cjelokupne prirodne filozofije na jednu jedinstvenu silu, odnosno na jedinstveni zakon silâ koji ravna ne samo 'zemaljskom' nego i univerzalnom svemirskom fizikom, nezaobilazno bivamo suočeni s pitanjem kako objasniti univerzalnost Boškovićeve sile, tj. njezinu primjenjivost i na mikrofiziku i na astrofiziku.

Povećavanjem udaljenosti između bezdimenzijskih točaka, sila se smanjuje do iščeznuća, zatim prelazi u privlačnu silu pa opet u odbojnu i nakon nekoliko takvih izmjena privlačna sila na sve većim i većim udaljenostima (koja odgovaraju svemirskim prostranstvima) asimptotski teži ništici. Matematičkim rječnikom kazano: na izuzetno malim i na izuzetno velikim udaljenostima Boškovićeva krivulja sile poprima oblik asimptotske krivulje, što u slučaju privlačnoga gravitacijskog luka znači da je sila obrnuto proporcionalna kvadratu udaljenosti između točaka.

I u ovome je slučaju važno istaknuti da sukladno zakonu neprekinutosti kod tih prijelaza nema nikakva skoka. Svi kontinuirani prijelazi i promjene sile (njezinih smjera i veličine) trebaju se, nepokolebljiv je Bošković, moći izraziti jednim algebarskim izrazom i geometrijski predočiti jednom jedinom krivuljom silâ. ${ }^{66}$

59

Usp. S. Kutleša, Prirodnofilozofijski pojmovi Ruđera Boškovića, str. 303.

60

»Est enim solemne illud hominibus, atque usitatum, quod quidem est maximorum praejudicorum fons, et origo praecipua, ut quidquid in nostris sensibus est nihil, habeamus pro nihilo absoluto.« - ThPhN, br. 159.

61

Usp. ThPhN, br. 143.

62

Prema standardnomu modelu elementarnih čestica (mnogostruko eksperimentalno potvrđenomu i najboljemu što za sada znanost ima), temeljne čestice od kojih se materija sastoji jesu kvarkovi (ima ih 6), leptoni (također 6) i baždarne čestice, koje su kvanti polja sila (međudjelovanja): foton polja elektromagnetske sile, gluon polja jake nuklearne sile, W-bozoni i Z-bozoni polja slabe sile. One su prijenosnici ili posrednici spomenutih sila ili tzv. silonoseće čestice. Samo za njih vrijedi tvrdnja da je materija sačinjena od poljâ ispunjenih silom. Kvarkovi i leptoni su materijalne čestice, dakle nisu polja. Materijalne čestice su lokalizirane i imaju svojstvo tromosti izraženo masom, dok je polje nelokalizirana vektorska (usmjerena) fizička veličina, zapravo prostor oko materijalne čestice ili tijela u kojem djeluje (električna, magnetska, gravitacijska) sila. Polje se teoretski proteže na čitav prostor, ali efektivno njegova jakost brzo opada (s kvadratom udaljenosti za električnu i gravitacijsku silu) tako da se kod većih udaljenosti djelovanje sile može zanemariti.

63

Usp. Helmut Moritz, Znanost, um i svemir. Uvod u prirodnu filozofiju, preveo Dušan Trbojević, Školska knjiga, Zagreb 1998., str. 181.

64

Usp. Ivan Macan, Filozofija spoznaje, Filozofsko-teološki institut Družbe Isusove, $\mathrm{Za-}$ greb 1997., str. 89-90.

65

Carl Friedrich von Weizsäcker, Der Garten des Menschlichen, Hanser, München 1977. str. 586.

66

Podrobnije o Boškovićevu tumačenju svoje sile i njoj pripadajuće krivulje usp. ThPhN, br. $167-188$. 
Na osobit se način u ovoj Boškovićevoj krivulji njegovo 'ispravno razmišljanje' očituje platonovskom ljepotom geometrijske domišljatosti koja je umješno i sretno združena s aristotelovskim metafizičkim poimanjem kontinuiteta:

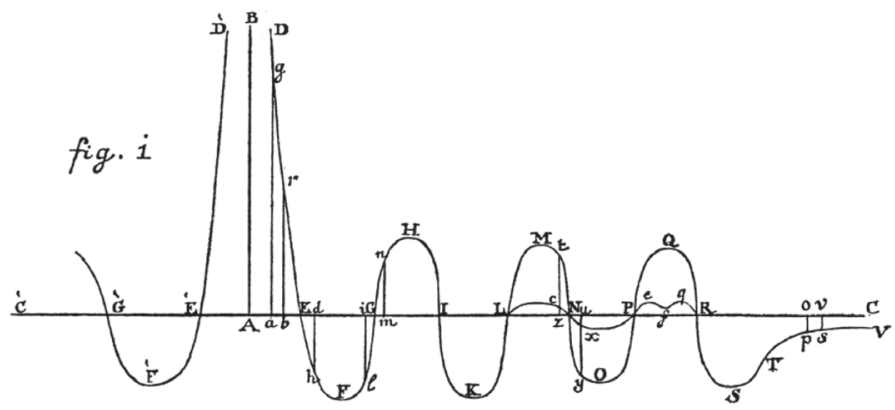

Konačni oblik Boškovićeve krivulje sile. Teorija prirodne filozofije, 1763., sl. 1.

Treba reći da je potencijalno beskonačna (beskonačno velika) odbojna sila, koja djeluje na beskonačno malim udaljenostima, ovdje opisana graničnim procesom: zato je pozivanjem na analogiju moguće pretpostaviti da se sila na beskonačno velikim udaljenostima dade opisati sličnim graničnim procesom. Dakako, čovjekova svakodnevica nije izravno upućena ni na mikrofiziku ni na astrofiziku, nego na neku osjetilima dohvatljivu 'makrofizičku' životnu okolinu koja se zatječe između tih krajnosti.

Dospijevamo do pitanja je li moguće Boškovićevu jedinstvenu silu - koja zahtijeva isključenje matematičkoga dodira - eksperimentalno potvrditi u svakodnevnom iskustvu.

»Sraz kugala, dodir primaknute ruke, udarac batine; eksperimentalne su činjenice koje navode Boškovića da postavi važno pitanje: 'Da li uistinu postoji dodir tjelesa?'. Dodir kao fizička situacija kojom se dokida udaljenost proturječi isključivom promatranju funkcionalne ovisnosti sile o udaljenosti. Stoga se Bošković eksperimentalno ustanovljenim realnostima suprotstavlja zaključkom: 'Pokazujemo očito da nas nije svladala niti istinitost niti lažnost takvih eksperimenata niti svjedočanstvo osjetila, jer u tim osjetilima ne može postojati baš nijedna osnova ma za što'. ${ }^{67}$

Ovdje nam se nezaobilazno nameće pitanje kako Bošković, polazeći od načela analogije i jednostavnosti prirode, dospijeva do ideje svojih jednostavnih, neprotežnih, nedjeljivih i bezobličnih točaka. Takve je točke moguće zamisliti, ali njihove primjere nije moguće steći osjetilima, niti nam osjetila mogu posredovati njihovu ideju. Do njih se dolazi samo refleksijom, kritičkim razmatranjem i korekturom idejâ, pod uvjetom da nas dobri (metafizički) razlozi navedu misliti da takve točke u prirodi postoje. ${ }^{68}$ Valja ponovno podsjetiti da ovakvo nastojanje koje smjera dospjeti do principâ zbilje s pomoću apstraktnoga umovanja, teoretizirajućim kombiniranjem pretpostavki neovisno o svakome iskustvu i eksperimentalnoj provjeri - nije u osnovi ništa drugo doli metafizička spekulacija. ${ }^{69}$

Ideju svojih spekulativnim mišljenjem naslućenih točaka Bošković obrazlaže sljedećim rečenicama:

»Služeći se refleksijom neće nam biti teško oblikovati takvu ideju. Naime, prije svega, kada shvatimo protežnost i složenost iz dijelova, pa kad to dvoje zaniječemo, već samim tim steći ćemo neku ideju neprotežnog i nedjeljivog, služeći se negacijom onoga čiju ideju imamo, isto tako kao što imamo ideju rupice niječući opstojnost one materije koja nedostaje na mjestu rupice. Međutim, pozitivnu ideju nedjeljive i neprotežne točke možemo steći geometrijom i idejom protežnog kontinuiteta koju dobivamo sjetilima, a za koju ćemo malo kasnije pokazati da je 
lažna. Mi ćemo otkriti sam izvor lažnosti. Međutim ona nas ipak dovodi do vrlo jasne ideje nedjeljivih i neprotežnih točaka.«70

U prethodnom je citatu razvidna Boškovićeva odvagnuta epistemološka pozicija koja izbjegava jednostranosti i zastranjenja kako empirizma tako i racionalizma. Premda je Bošković i u spoznajnoteorijskome i u metodološkome pogledu bliži racionalizmu nego empirizmu, ostaju važne pojedinosti u kojima je njegovo stajalište različito od racionalističkoga. Prije svega se to odnosi na urođene ideje (ideae innatae). Naime, Bošković odbacuje urođenost bilo koje ideje i urođenost samoga pristanka na njih. Ali prihvaća urođenost sposobnosti/mogućnosti/moći pristanka uz načela i postavke što ih racionalisti neopravdano smatraju urođenim idejama. Drugim riječima, Bošković ta načela i te postavke priznaje samo kao izvornu sposobnost duha, a ne kao njegov aktualni habitus. Primijetimo da je opet posrijedi aristotelovsko-skolastička dihotomija potencijalno - aktualno. ${ }^{71}$

Od presudne cee se važnosti pokazati Boškovićevo odbijanje mogućnosti da ideje nalikuju samoj stvarnosti, stvarima i pojavama kakve su u sebi. Da je kojim slučajem, poput Descartesa, pridavao presudnu važnost 'jasnim i razgovijetnim (odjelitim) idejama' (ideae clare et distinte) ${ }^{72}$ zasigurno ne bi dospio do vjerodostojnih uvida o mikrosvijetu. Naime, teško je jasno i razgovijetno pojmiti da neprotežne točke mogu tvoriti nešto protežno jer, pojednostavljenim matematičkim rječnikom kazano, umnožak ma kako velikog broja i ništice uvijek daje ništicu. Bošković se pri rješavanju te poteškoće opet oslanja na aristotelovsko-skolastičku analogiju bitka, odnosno na metafizičko učenje o (matematičkoj) potencijalnosti i (fizičkoj) aktualnosti:

67

I. Martinović, »Temeljna dedukcija Boškovićeve filozofije prirode $\ll$, str. 60

68

Usp. V. Bajsić, »Pojam i značenje Boškovićeva principa indukcije $\ll$, str. 54.

69

Obezvrjeđujuće i čak pogrdno značenje pojma 'spekulacija' nastalo je u novome vijeku. Tomu je doprinijela i Kantova kritika, koja ovim pojmom najčešće označuje prekoračivanje osjetilnoga iskustva u spoznajnome procesu, ali isto tako i prekoračivanje mogućnosti znanstvene provjere toga iskustva. Dakle, takvo bi se prekoračivanje spoznaje protezalo prema nečemu što se načelno ne može ni iskusiti, pa time ni vjerodostojno spoznati. Stoga se to kao nešto 'izmišljeno' ne može ni obrazložiti. Nerijetko se u takvome obezvrjeđujućem kontekstu rabi sintagma 'puka spekulacija'. Usp. A. Halder, Filozofijski rječnik, str. 340-341.

70

»Reflexione adhibita non ita difficulter efformabimus nobis ideam ejusmodi. Nam inprimis ubi et extensionem, et partium compositionem conceperimus; si utranque negemus; jam inextensi, et indivisibilis ideam quandam nobis comparabimus per negationem illam ipsam eorum, quorum habemus ideam; uti foraminis ideam habemus utique negando existentiam illius materiae, quae deest in loco foraminis. Verum et positivam quandam indi- visibilis, et inextensi puncti ideam poterimus comparare nobis ope Geometriae, et ope illius ipsius ideae extensi continui, quam per sensus hausimus, et quam inferius ostendemus, fallacem esse, ac fontem ipsum fallaciae ejusmodi aperiemus, quae tamen ipsa ad indivisibilium, et inextensorum ideam nos ducet admodum claram. $\ll-T h P h N$, br. 133-134.

71

Usp. Dario Škarica, Spoznaja i metoda u Ruđera Boškovića, Hrvatsko filozofsko društvo, Zagreb 2000., str. 45-46; usp. Stipe Kutleša, Ruđer Josip Bošković, dvojezično izdanje, Tehnički muzej, Zagreb 2011., str. 55.

72

Slijedeći Platona Descartes polazi od urođenih ideja, a konačnu sigurnost nalazi u samoizvjesnosti mišljenja koje se zrcali u jasnim i razgovijetnim idejama. Iz toga jasno proizlazi da Descartes dedukciju sa silogističkim rasuđivanjem i otkrivanjem analognih veza drži temeljnim postupkom iznalaženja istine; a samo prilikom složenijih prirodoznanstvenih problema on se utječe $\mathrm{i}$ indukciji. Kod Descartesa dakle nije riječ o posvemašnjemu zanemarivanju osjetilnog iskustva, odnosno spoznajne pomoći što je pružaju eksperimenti, nego je riječ o davanju značajne prednosti racionalističkoj metodi od koje on očekuje da intuitivnim uvidom izvodi kriterij sigurne i istinite spoznaje. Usp. I. Supek, Ruđer Bošković, str. 35. 
»Ako bi mi dakle netko rekao da neprotežne točke i ti neprotežni načini postojanja ne mogu sačinjavati nešto protežno, ja bih mu jednostavno odgovorio da ne mogu sačinjavati nešto protežno matematički kontinuirano, ali da mogu sačinjavati nešto protežno što je fizički kontinuirano, $(\ldots) \ll^{73}$

Važno je uvidjeti da Bošković na spoznajnome putu od vidljive fizičke protežnosti i fizičkoga kontinuiteta dospijeva do svojega osjetilima nedostupnog 'modela atoma'. Premda su već starogrčki atomisti spekulirali kakva bi svojstva trebale imati najsitnije čestice tvari, problem atomske strukture pojavljuje se tek kada engleski fizičar i kasniji dobitnik Nobelove nagrade Joseph John Thomson godine 1897. otkriva elektron kao sastavni dio atoma.

Bivajući dobro upoznat s Boškovićevom prirodofilozofijskom teorijom, J. J. Thomson vlastitu pretpostavku atomske strukture izravno izvodi iz njegove krivulje sila i njegova 'modela atoma' koji iz te sile dosljedno proishodi. ${ }^{74}$

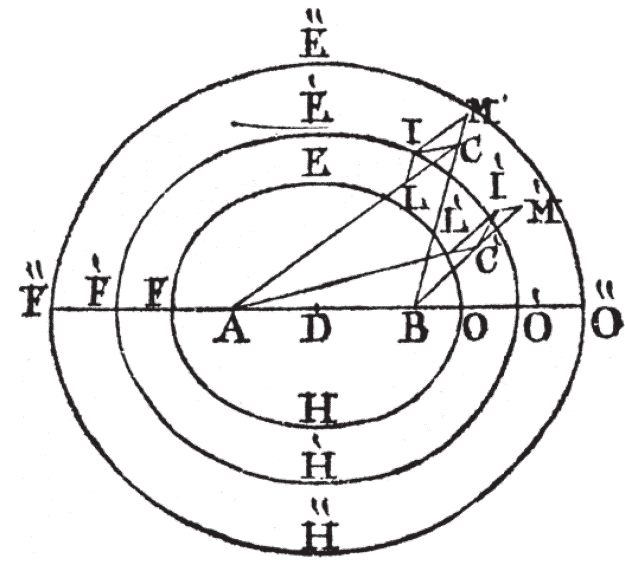

Boškovićev 'model atoma'.

Ponašanje točke kada se nalazi između elipsi kohezije i nekohezije. Teorija prirodne filozofije, 1763., sl. 33.

Kako bi izbjegao određene fizikalne poteškoće sa svojim atomskim modelom, Thomson pretpostavlja da postoje samo neke staze po kojima se elektroni mogu gibati, tj. da iz tih staza ne mogu izići. Tragajući za teorijskom podlogom te zamisli, engleski fizičar je pronalazi u Boškovićevoj ideji 'dopuštenih' i ‘zabranjenih' staza, dobro pretpostavljajući da u atomskim razmjerima vrijedi Boškovićev zakon sila. ${ }^{75}$ Zato će se elektron nahoditi na jednoj od koncentričnih elipsi koje se ponašaju kao granice kohezije i nekohezije (nultočke na krivulji, njezina presjecišta s apscisom, gdje se izmjenjuju odbojna i privlačna sila). ${ }^{76}$ Dokaz utemeljenosti Thomsonovih, a time i Boškovićevih, mogućih staza slijedi tek nakon što Max Planck objavljuje svoju kvantnu teoriju a Niels Bohr usvaja koncept diskretnih staza.

Iako Boškovićevoj teoriji možemo pripisati samo posredan utjecaj na izgradnju Bohrova modela atoma, razmjerno je lako dokazati da je Boškovićevo poimanje atomske strukture elegantno uskladivo sa svim rezultatima Bohrove teorije. Štoviše, jedino se iz Boškovićevih razmatranja o 'dopuštenim' i 'zabranjenim' stazama, uz postavljanje određenih uvjeta, mogu izvesti Bohrovi postulati. Bošković potrebu uvođenja 'dopuštenih' i 'zabranjenih' stazâ (makar te pojmove nije nikad izričito rabio) opravdava spekulacijom o sustavu s tri točke od kojih se jedna giba po točno određenim elipsama. On lucidno spekulira da 
»... može biti velik broj mjesta i na površini sferne čestice koja jednu česticu na istoj udaljenosti od središta privlače ili je odbijaju, ili pak koja nikako ne djeluju, jer na tim mjestima može biti više ili manje točaka nago na drugim mjestima; osim toga mogu biti smještene na raznim udaljenostima od središta i na raznim međusobnim udaljenostima. Odatle se može dogoditi i to da (...) neku točku jedna od dviju točaka privlači, a druga tu istu odbija, pa zbog utjecaja sastavljene sile biva potiskivana u stranu; a tako isto jednu česticu može privlačiti jedan dio druge, dok je drugi dio koji leži u drugom smjeru može odbijati, te tako isto biva potiskivana u stranu; pa pošto je s obzirom na nju došla u određen položaj, ona je determinirana da ga čuva. «77

U isto vrijeme kada Boškovićeva teorija kojom je objašnjavao strukturu atoma zaokuplja J. J. Thomsona, njome se bavi i lord Kelvin. Tada je napose aktualno pitanje na koji način je elektron, kao dio atoma, povezan s ostalim dijelovima mikrosvijeta što čine atom. Premda je Kelvin isprva imao poteškoća s prihvaćanjem Boškovićeve teorije o subatomskim česticama, godine 1907. u Philosophical Magazine izjavljuje da njegova najnovija pretpostavka nije ništa drugo nego »izvorni i jednostavni boškovićizam« (engl. »My present assumption is Boscovichianism pure and simple.«). ${ }^{78}$

$\mathrm{Ne}$ inzistirajući na fizikalnoj prirodi elektrona, možemo ga skupa s isusovačkim filozofom Henryjem V. Gillom razumjeti kao neprotežnu točku koja je združena s nekim poljem sila. Analogno se može smatrati i za druge čestice od kojih je atom sastavljen. ${ }^{79}$ Zbog mnogih i kompleksnih teorijskih razloga, koje ovdje nije moguce spomenuti, u današnje doba fizičari smatraju da ni takve subatomske čestice nisu elementarne, nego da se sastoje od još manjih djelića koji su nazvani kvarkovi. Otkriće 'kvarkovnog sužanjstva' 1963. godine potvrđuje Boškovićevu hipotezu većeg broja odbojnih polja i čestica različitih redova i struktura. Štoviše, ustanovljeno je da se kvarkovi u svakoj razini, dakle kvarkovi bilo kojeg reda, ponašaju upravo kao Boškovićeve točke. ${ }^{80}$ Također se i subatomske čestice leptoni (elektron, mion, tau-čestica, neutrino) mogu povezati s modelom Boškovićeve materijalne točke (puncta materiae).

Stoga H. V. Gill s punim pravom primjećuje:

»Gdje je Bošković posadio prije dvije stotine godina, drugi su požnjeli (...).« ${ }^{81}$

73

»Porro si quis dicat, puncta inextensa, et hosce existendi modos inextensos non posse constituere extensum aliquid; reponam facile, non posse constituere extensum mathematice continuum, sed posse extensum physice continuum, (...).«-ThPhN, br. 372

74

Usp. S. Kutleša, Prirodnofilozofijski pojmovi Ruđera Boškovića, str. 215.

75

O značajkama Boškovićeve teorije sile u odnosu na sile u modernoj fizici usp. Ivo Šlaus, »Sile u modernoj fizici i u Boškovićevoj 'Teoriji' «, u: V. Pozaić (ur.), Filozofija znanosti Ruđera Boškovića, str. 89-102.

76

Usp. S. Kutleša, Prirodnofilozofijski pojmovi Ruđera Boškovića, str. 211.

77

»... posssunt esse loca quotcunque in superficie particulae etiam sphaericae, quae alteram particulam in eadem a centro distantia sitam attrahant, quae repellant, quae nihil agant; cum nimirum in iis locis possint vel plura, vel pauciora esse puncta, quam in aliis, et eam ad diversas a centro, et a se invicem distantias collocata. Inde autem et illud fieri poterit, ut (...) unum punctum a duorum aliorum altero attractum, ab altero repulsum, vi composita urgetur in latus, ita etiam una particula $a b$ una alterius parte attracta, et repulsa ab altera in altera directione sita, urgeatur itidem in latus, et certam assecuta positionem respectu ipsius, ad eam tuendam determinetur (...).« - ThPhN, br. 423 .

78

Citirano prema: Ž. Dadić, Ruđer Bošković, str. 122

79

Usp. Henry Vincent Gill, Roger Boscovich S. J., (1711-1787). Forerunner of Modern Physical Theories, Gill and Son, Dublin 1941., str. 6.

80

Usp. Ž. Dadić, Ruđer Bošković, str. 128-129.

81

H. V. Gill, Roger Boscovich S. J., str. 26. 
Ništa manje utemeljeno zaključuje:

»Kada se bude pisala povijest atomske teorije, pravo bi bilo da se uloga koju je odigrao otac Ruđer Bošković ne smije previdjeti. $\ll^{82}$

Vidjeli smo da se u Boškovićevu poimanju materija gotovo u potpunosti sastoji od praznoga prostora ispunjenog silama. Današnji fizičari običavaju slikovito kazati da se 99,99 posto atoma sastoji od praznoga prostora. Bošković se prvi u povijesti odvažio izreći smionu tvrdnju da bi pri dovoljno velikim brzinama (koje doduše ne određuje kvantitativno) tijela mogla prolaziti jedna kroz druga, a da pritom ne dođe do promjenâ njihove unutarnje strukture. Bošković čak kaže slikovit primjer da bi čovjek gibajući se takvim velikim brzinama mogao nesmetano proći kroz vrata ili zid, tako da njegovo tijelo ostane neozlijeđeno a objekti kroz koje je prošao neoštećeni. ${ }^{83}$ Premda se danas ne zna hoće li ikada biti ostvarene dovoljno velike brzine za takve nesmetane prolaze, relativistička kvantna fizika teorijski prihvaća kompenetracije makroskopskih tijela na način kako ih je Bošković pretpostavio. ${ }^{84}$

Teško je na osnovi svega rečenog razumjeti zašto je Bošković u širim populacijskim krugovima izvan Hrvatske ostao gotovo nepoznat. Recimo, njegovo se ime - za razliku od imenâ kao što su Galilei, Newton, Kepler, Descartes, Leibniz, Locke, Hume, Kant itd.$^{85}$ - gotovo u pravilu ne nalazi na stranicama gimnazijskih udžbenika koji nisu objavljeni u Hrvatskoj. Možda korijene odgovora na ovo pitanje valja tražiti u činjenici da je Bošković odlučno odbacio mehanicistički materijalizam i tako navukao srdžbu francuskih prosvjetitelja. Poneseni osobnom netrpeljivošću, kako u zanimljivom i nadahnutom eseju piše Tin Ujević, Boškoviću su »u Francuskoj napakostili opaki enciklopedisti, a napose D'Alambert «. ${ }^{86}$ Odbojnost je dodatno potaknuta činjenicom da je Bošković isusovac, pripadnik crkvenoga reda izloženog u drugoj polovici 18. stoljeća nesmiljenim napadima gotovo sa svih strana: kako mnogih monarha, tako i znatno brojnijih tzv. 'slobodoumnih mislilaca'. Isusovački je red u Boškovićevoj starijoj životnoj dobi ukinut, a nepuna dva desetljeća nakon Boškovićeve smrti ukinuta je i Dubrovačka Republika. U nedovoljnome vrednovanju ovoga svjetski značajnoga filozofa i znanstvenika također se zrcali i sudbina hrvatskoga naroda koji se zbog relativne malobrojnosti i apsolutne političke neslobode nije mogao odlučno i vjerodostojno ispriječiti zapostavljanju intelektualne ostavštine svojega izuzetno zaslužnog pripadnika.

Prikladno je u tome smislu navesti misli neoskolastika Stjepana Zimmermanna koje su i danas, nakon osam desetljeća, još uvijek životne i aktualne:

»Danas kao da gasne pred našim očima svjetlost idealnih vrijednosti, i kao da se hoće oduzeti hrvatskom narodu smisao za onaj kulturni napredak, koji se i ne sastoji, a kamo da bi se iscrpio u kolektivnim stvaranjima bez intelektualnih pojedinaca. (...) Kad bi narod nepravedan bio prema nekome samo zato što je 'jezuit', ne bi ni imao Boškovića. Kao što isusovac Bošković nije konvenirao pariškoj koteriji jednog d'Alamberta, tako će možda i naši 'slobodoumnici' nastojati da Boškovića zataje ili bar iskrive. $\ll^{87}$

Ipak, koliko god se navedeni razlozi doimali utemeljenima, oni zaobilaze najvažniji uzrok neprimjerenoga vrednovanja Ruđera Boškovića. A taj uzrok treba prepoznati u Boškoviću samom. Naime, upravo je ovaj temperamentni i znatiželjni zasebnik najveći 'krivac' za takvo stanje stvari - i to zbog vlastite neusklađenosti s vremenom, njegovim duhom i zakonitostima. Sve ono što podsjeća na formalizam, patetiku i ironiju unutar netom iskazane teze, svojim će rečenicama u poglavlju naslovljenom »Dalmatinski prorok « razgraditi Leon Lederman, dobitnik Nobelove nagrade za fiziku: 
»Fraza 'išao je ispred vremena' često se i prečesto rabi. Ali ja ću je ipak upotrijebiti. Ne govorim o Galileju niti o Newtonu. Obojica su stigli baš u pravo vrijeme, ni prerano ni prekasno. Gravitacija, obavljanje pokusa, mjerenje, matematički dokazi... sve te stvari visile su u zraku. Galilei, Kepler, Brahe i Newton bili su prihvaćeni - čak slavljeni uz fanfare! - u vlastitom vremenu zato što su stigli sa zamislima koje je znanstvena zajednica bila spremna prihvatiti. Nisu bili svi te sreće. Hrvat Ruđer Josip Bošković, Dubrovčanin koji je veliki dio svog radnog vijeka proveo u Rimu, rođen je 1711., šesnaest godina prije Newtonove smrti. (...) Bošković je tvrdio da su Newtonovi zakoni gravitacije 'gotovo savršeno točni, ali da određena odstupanja od zakona obrnute razmjernosti s kvadratom udaljenosti, premda vrlo malena, ipak postoje'. Nagađao je [služio se dakle metafizičkom spekulacijom; op. M. M. L.] da će se taj klasični zakon morati srušiti u atomskim razmjerima gdje se sile privlačenja zamjenjuju privlačnim i odbojnim silama koje se naizmjence smjenjuju ovisno o udaljenosti. Nevjerojatna zamisao za znanstvenika osamnaestog stoljeća. ${ }^{88}$

Samosvojnim i smislenim posredovanjem - koje nije puka reprodukcija preuzetih sadržaja, nego njihova odvagnuta reafirmacija i plodonosna predaja budućnosti - Ruđer Bošković uvodi najstariju filozofsku tradiciju u nove spoznajnoteorijske uvide, anticipirajući tako dosege fizikalne znanosti u, za njegovo doba, razmjerno dalekoj budućnosti 19. i 20. stoljeća. Na taj je način najbolje pokazao da je aristotelovsko-skolastička misao jedna istinska i sveopća filozofija neograničena trajanja (philosophia perennis), filozofija čiji je sadržaj trajno prisutan ne samo u izmjenjivim misaonim sustavima tijekom povijest filozofije nego i u suvremenim fizikalnim teorijama.

Pitagorina 'matematička metafizika', Empedoklove privlačne i odbojne sile, Heraklitove naizmjenične promjene ostvarene u jedinstvu i borbi suprotnosti, Parmenidov apsolutni identitet, Demokritovo učenje o atomima, Platonove kozmologijske ideje o geometrijskoj strukturi materije i njegov metafizič-

82

Ibid., str. 30 .

83

Usp. ThPhN, br. 370 .

84

Ruđer Bošković govori o tzv. »prividnoj kompenetraciji« (apparenti compenetratione) isključujući »pravu kompenetraciju« (vera compenetratione) čime u nekoj mjeri anticipira suvremene kvantnomehaničke proračune koji za makroskopska tijela daju, iako različitu od nule, ali praktično ipak zanemarivu (1 prema 10 na potenciju reda 100$)$, vjerojatnost prolaska makroskopskoga tijela kroz potencijalnu barijeru. Za razliku od makroskopskih tijela, elementarne čestice, npr. neutrino koji se giba praktički brzinom svjetlosti, prolaze kroz materiju posve slobodno bez gotovo nikakve interakcije s njom, upravo na tragu Boškovićeve genijalne pretpostavke da je uvjet za kompenetraciju velika brzina gibanja tijela odnosno čestica. Usp. također S. Kutleša, Prirodnofilozofijski pojmovi Ruđera Boškovića, str. 184-186.

85

Premda Bošković nije zaobiđen u mnogim svjetski poznatim i cijenjenim leksikonskim i enciklopedijskim izdanjima, još uvijek se kao općeniti dojam može reći da nije dobio mjesto koje po svojoj važnosti zavrjeđuje. U tome smislu može biti zanimljiv podatak da u The New Encyclopaedia Britannica članak iza natuknice »Boscovich, Ruggerio Giuseppe« zauzima znatno manji prostor u usporedbi s prostorom koji je posvećen drugim velikanima novovjekovne znanosti i filozofije. Primjerice, Galilei je u toj enciklopediji dobio oko deset puta više prostora nego Boš ković, a Newtonu je pripalo čak dvadesetak puta više prostora u odnosu prema Boškoviću. Usp. The New Encyclopaedia Britannica (ur. Robert P. Gwinn), sv. 2, Encyclopaedia Britannica, Inc., Chicago, Auckland, Ženeva, London, Manila, Pariz, Rim, Seul, Sidney, Tokio, Toronto 1974. - 1995., str. 399; sv. 19, str. 638-640; sv. 24, str. 931-935.

86

Tin Ujević, »Sa sjajem jedne zvijezde. Pater Ruđer Bošković, barokni jezuit i gospar iz dekadentnog Dubrovnika kao čovjek svog doba«, Eseji II, August Cesarec, Slovo ljubve, Zagreb, Beograd 1979., str. 52.

87

Stjepan Zimmermann, »Boškovićev filozofski nazor o svijetu«, O hrvatskoj filozofiji $i$ kulturi, Hrvatska sveučilišna naklada, Zagreb 2001., str. 78

88

Leon Lederman, Dick Teresi, Božja čestica: ako je svemir odgovor, što je pitanje?, preveo Ruđer Jeny, Izvori, Zagreb 2000., str. 134. 
ko-matematički apriorizam, Aristotelovo poimanje neprekinutosti i njegova analogija bitka u modalnim određenjima potencijalnosti i aktualnosti - pročišćeni su, prerađeni, nadograđeni i prilagođeni te su kao takvi ugrađeni u Boškovićevu sliku prirode, njegov oštroumno zamišljeni 'Novi svijet', tj. nužnu i univerzalnu zakonitost koja ostvaruje sve svjetove: apsolutni dinamizam.

Sveprožimajuća Boškovićeva sila u odnosećem prostoru međudjelovanja uzajamno je prožela i nadišla suprotstavljenosti koje su do tada razumijevane kao 'materija' i 'duh'. Premda su mnogi Boškovićevi interpreti skloni tvrditi da je on desupstancijalizirao materiju, što je u određenom smislu istina, to nipošto ne znači da je izjednačio materiju i duh niti da je smatrao kako je svako jednostavno i neprotežno biće ujedno i misaono, što su mu podmetali neki protivnici koji su mahom polazili od kartezijanske podjele zbiljnosti na res cogitans i res extensa.

Boškoviću je sila 'prvotnija' od tvari. On je polazeći od sile dospio do svojih neprotežnih atoma. Nije li stoga razložno pomisliti da bi Boškovićevu jedinstvenu silu, čije je geometrijsko oličenje simetrična krivulja koju je on smatrao najjednostavnijom, zapravo trebalo smatrati supstancijom? Uzme li se u obzir da je Bošković svoju čitavu prirodofilozofijsku teoriju sveo na 'jedan jedini zakon sila koje postoje u prirodi', te da je Werner Heisenberg postulirao da na početku materijalnog svijeta, u njegovu iskonu, stoji platonovska simetrija - zaista se čini razložnim i argumentiranim Boškovićevu jedinstvenu silu okarakterizirati supstancijalnom.

Međutim, ta je razložnost samo prividna, a iz nje proistekla argumentacija zasnovana na pogrešnim premisama. Ne bismo smjeli dopustiti da nas bilo što svojom zavodljivošću odvuče podalje od ispravnoga razumijevanja same bîti Boškovićeve prirodne filozofije. Ovo je ključno: u njegovoj filozofiji prirode sila ne može postojati bez tvari (osim u nekome čisto pneumatološkom i teološkom smislu), niti tvar može postojati bez sile. A ni jedna ni druga ne mogu postojati bez prostora i vremena, kao ni prostor i vrijeme bez njih. Sve te fizičke pojavnosti nalaze se u jednom 'paketu' koji se održava jedinstvenim zahvaljujući simultanim i višestruko uvjetovanim međuuzročnostima. Zato bi se, uz neke ograde i dodatna objašnjenja, Boškovićeva metafizička slika fizičkoga svijeta mogla označiti kao 'monizam supstancije sui generis'.

Važno je uvidjeti da ovdje nipošto ne može biti riječi o bilo kakvoj panteističkoj misli o jedinstvu svijeta. Za razliku od renesansnih poimanja i Spinozina, Boškoviću Bog i priroda nisu jedno. Bog je tvorac prirodnih zakona, ali oni na Boga nisu primjenjivi - odlučan je u tomu Bošković - jer bi tada bila dokinuta Božja beskrajna moć i neograničena sloboda. Štoviše, Bošković smatra da se ni na čovjeka, odnosno na njegovu dušu i tijelo, ne mogu primijeniti jedni te isti zakoni. Ovaj se naš novovjekovni mislilac pomno nastoji ukloniti i svim poteškoćama pri određenju tjelesne i duhovne supstancije, poglavito onim misaonim tjesnacima u koje su zapali Descartesovi i Leibnizovi pristaše. ${ }^{89}$ Bošković zakone koji se odnose na dušu i tijelo, odnosno njihovo metafizičko ujedinjenje, razmatra uviđavno i odmjereno:

»Nadalje, veza između duše i tijela, koju nazivamo ujedinjenjem, ima tri međusobno različite vrste zakona, od kojih su dvije posve različite i od one vrste zakona koja postoji među točkama materije, dok se treća vrsta samo donekle s njom poklapa, ali se u mnogo većoj mjeri od nje veoma razlikuje, tako da ta vrsta stoji daleko od svakog materijalnog mehanizma. (...) Nalazi li se duša u jednoj jedinoj točki prostora koju ne zauzima nijedna točka materije, pa odatle ima vezu s drugim točkama s obzirom na koje ima sve one zakone lokalnih i tipično duhovnih pokreta [...], ja smatram da to iz samih prirodnih pojava, a i razmatranjem i razmišljanjem o svemu što stoji s njima u vezi, nećemo nikada saznati. ${ }^{90}$ 
Navedeni citati vjerno pokazuju Boškovićevu razboritu skepsu, odnosno djelomični skepticizam glede mogućnosti spoznaje nekih aspekata i slojeva zbilje. On ne želi nasilno prilagođavati složene i nedokučive prirodne fenomene svojoj teoriji, nego upravo suprotno: fenomene pokušava objasniti vlastitom teorijom, a ako ustrajno izmiču primjerenom i prihvatljivom objašnjenju, tada je spreman priznati neznanje i nemoć. Budući da je djelomični skepticizam (a potpuni pogotovo) znatno svojstveniji filozofima nego znanstvenicima - Bošković se i u ovom slučaju iskazao ponajprije i ponajvećma filozofom. Boškovićevu su prirodnu filozofiju - upravo zbog njezine kompleksnosti, jedinstvenosti i nesvodivosti na bilo koji filozofski pravac ili školu mišljenja - pogrešno razumijevali i filozofi i znanstvenici. Do zabluda ih je mahom doveo redukcionistički i simplicistički pristup Boškovićevu misaonom sustavu, napose njegovim atomima i njegovoj sili. Bit će dovoljno spomenuti dva primjera.

Engleski kemičar, filozof i teolog Joseph Priestley bio je prvi Boškovićev pristaša na Otočju. Boškovićevu teoriju primjenjuje u nekim svojim radovima iz optike, ali kada u filozofskome djelu o odnosu tvari i duha (Disquisitions Relating to Matter and the Spirit, 1777.) njegovu teoriju povezuje s materijalizmom, Bošković mu izražava negodovanje oštro intoniranim pismom te se s njim upušta u gorljivu prepisku.

Drukčije usmjerenu jednostranost pokazuje Friedrich Nietzsche. Njega je, premda preziratelja kršćanskoga 'kreposnog i pokornog mentaliteta stada' te gorljivoga protivnika svećenstva i metafizičke tradicije, oduševila filozofija prirode jednog isusovca. Nije međutim dovoljno poznato je li Nietzsche uočio metafizičko utemeljenje prirodoznanstvene teorije Ruđera Boškovića. Hvali ga zbog njegove pobjede nad osjetilnošću, naivnom empirijom i vulgarnim materijalističkim shvaćanjem tvari - u čemu Nietzsche načelno ima pravo - ali propušta uvidjeti da je Boškovićeva pobjeda nad naivnom vjerom u nepovredivi autoritet osjetilâ, izvojevana metafizičkom doktrinom i metafizičkim oružjem. Važno je spomenuti da je Nietzscheova sklonost Boškovićevoj teoriji zapravo potaknuta time da je njemački filozof u Boškovićevoj sili koja je 'dematerijalizirala svijet' pronašao opravdanje za svoj nihilizmom poneseni voluntarizam.

Premda se iz Boškovićevih djela ne može posve jasno i jednoznačno zaključiti smatrao li je podjelu na materiju i duh ontološkom/stvarnom ili samo epistemološkom/razgraničujućom; može se pouzdano ustanoviti da je Bošković, nošen naletom silovite i zbunjujuće smislenosti, već u 18 . stoljeću ponudio prilično jasne nagovještaje i predoblike kvantne fizike. Niels Bohr dva stoljeća nakon toga tvrdi da su materijalizam i spiritualizam 'dva aspekta iste stvari', ne propuštajući pritom više puta dosljedno istaknuti Boškovićeve zasluge za stvaranje kvantnih koncepcija. Naime, da se u novovjekovlju unutar nečijeg mentalnog ambijenta mogla roditi ideja o neprotežnim točkama koje

89

Usp. ThPhN, »Dodatak, koji spada u metafiziku, o duši i Bogu« (»Appendix, ad Metaphysicam pertinens, de anima, et Deo $\ll)$, br. 525-529.

90

»Porro commercium illud inter animam, et corpus, quod unionem appellamus, tria habet inter se diversa legum genera, quarum bina sunt prorsus diversa ab ea etiam, quae habetur inter materiae puncta, tertium in aliquo genere convenit cum ipsa, sed ita longe in aliis plurimis ab ea distat, ut a materiali mechanismo penitus remotum sit. (...) An ipsa existat in unico puncto spatii, quod a nullo materiae puncto occupetur, et inde nexum habeat cum certis punctis, respectu quorum habeat omnes illas motuum localium, et animasticorum leges (...); id sane ex puris Naturae phaenomenis, et vero etiam, ut arbitror, ex reflexione, et meditatione quavis, quae fiat circa ipsa phaenomena, nunquam nobis innotescet.« - Ibid., br. 531, 534. 
nisu Leibnizovi 'duševni atomi', nego je od njih sastavljena protežna materija - zaista nije lako razumjeti bez osjećaja čuđenja ili čak zapanjenosti. U tom je smislu poželjno vratiti se Leonu Ledermanu i nastavku njegova živopisnog objašnjavanja Boškovićeva dalekosežnog nesklada s vremenom kojemu je biografski pripadao:

»Bošković je imao još jednu zamisao, potpuno luđačku za osamnaesto stoljeće (a možda i za bilo koje drugo vrijeme). Materija je građena od nevidljivih i nedjeljivih a-toma, rekao je. Dobro, to nije posve novo, s tim bi se složili i Leukip, Demokrit, Galilei, Newton i drugi. Ali čujte novu stvar: Bošković je tvrdio da te čestice nemaju veličinu, naime da su geometrijske točke. Nazvao ih je 'puncta', latinski 'točka'. Jasno je, kao i kod mnogih drugih zamisli u znanosti, da se za ovo mogu naći nagovještaji u radovima ranijih znanstvenika, vjerojatno već kod starih Grka, a naravno i kod Galileja. Kao što ste možda zapamtili na satovima geometrije u srednjoj školi, točka je samo mjesto. Bez dimenzija. A Bošković tvrdi, ni manje ni više, da je materija građena od čestica koje nemaju dimenziju! Mi smo, evo prije dvadesetak godina, pronašli česticu koja odgovara tom opisu. Nazvali smo je kvark.«91

Do slutnje ovakvih čestica na subatomskoj razini Boškovića dovodi metafizička spekulacija, njegova osobita i osebujna kvalitativna metoda, ${ }^{92}$ kao jedna od ključnih sastavnica već spominjanoga misaonog postupka poznatog kao 'ispravno razmišljanje'. Posrijedi je osebujno problematiziranje i tematiziranje prirode, gdje se misao obazrivo obraća onim sadržajima koji su u temeljima pojavne zbilje u 18. stoljeću bili posve neiskusivi. Pomno odabranim geometrijskim algoritmima i metafizičkim kategorijama okrepljuje Bošković svoju prirodnu filozofiju i tako je dostojno čuva od nedostojne ovisnosti o svjetonazorski oblikovanim antropocentrizmima, odnosno optimizmom ponesenim tlapnjama kojima se u njegovo doba zavaravaju mnogi novovjekovni umovi bezuspješno pokušavajući nadmudriti prirodu i tako nadvladati nespoznatljivost pojavnoga svijeta.

\section{Zaključna perspektiva}

U predgovoru bečkoga izdanja Boškovićeva kapitalnog djela nahodimo programatsku i vizionarsku rečenicu:

»Dragi čitaoče, pred sobom imaš Teoriju prirodne filozofije izvedenu iz jedinstvenog zakona sila. $« 93$

Navedena bi rečenica trebala to većma nadahnjivati suvremene znanstvenike i filozofe znanosti tako da u njoj prepoznaju prastaru filozofijsku odnosno metafizičku težnju da se svijet spozna i misaono obuhvati što manjim brojem jednostavnih principa (počela) koji su pojmljeni kao supstancije, praelementi, pratemelji i prauzroci svega pojavnog svijeta. Iako se metafizika u svojemu propinjanju i uzletu prema objektivnosti, istini i znanju uzdiže na najviši stupanj apstrakcije, ona time ne iznevjerava konkretnost stvarî koje su njezinim kategorijama, principima i pojmovima obuhvaćene i svrstane.

Važnim ostaje uvidjeti da je Bošković i onodobnim i današnjim i budućim znanstvenicima jasno pokazao da razvoj prirodnih znanosti ne treba - a to ujedno ima značiti i da ne smije! - biti razumijevan isključivo kao interakcija empirijskokvantitativnih podataka i metodološke interpretacije pojmova koji su na tim podatcima zasnovani (a ti se pojmovi u povratnoj sprezi primjenjuju na iskustvene i mjerljive podatke). Potrebno je, dakle, na Boškovićevu tragu otkloniti takav neprevladani i naivni pozitivističko-scijentistički pristup, tj. pogled, svjetonazor i program koji priznaje dignitet znanstvenosti samo onoj znanosti koja počiva na eksperimentima, provjerljivim činjenicama i mjerljivom iskustvu. 
Boškovićevo metafizičko prirodoslovlje autentičan je primjer susreta jedincatosti i univerzalnosti, prožimanja novovjekovnoga duha i daha svevremenosti, međuigre neodoljive jednostavnosti i izmičuće pojmljivosti čovjekovim na iskustvu zasnovanim uvidima. Boškovićeva je teorija u onom dijelu koji se odnosi na zakon silâ i strukturu tvari iscrtala na mapi prirodne znanosti novu i bitno drukčiju topografiju, otvorivši nove perspektive koje još uvijek nisu do kraja sagledane i kao takve ostaju otvorene možebitnim i očekivanim plodonosnim reafirmacijama. Perspektive su to iz čijih nedogleda s pravom očekujemo dimenzije budućnosti Boškovićeve prirodoznanstvene teorije. Iako se u tom smislu Boškovićevu imenu redovito i opravdano predmeću apozicije anticipator, vizionar, prorok i sl. - izvjesno je da ni on sâm nije mogao do kraja pojmovno uobličiti proplamsaje vlastite lucidnosti a kamoli predvidjeti njezine prirodoznanstvene i tehničke dosege.

\title{
Marito Mihovil Letica
}

\section{Scientific and Technological Outreach of Boscovich's Metaphysical Natural Philosophy}

\begin{abstract}
In this paper it is highlighted and argued that Boscovich's natural sciences theory is so deeply rooted in metaphysics and pervaded by it, we can maintain that it is a distinctive example of sharp-witted, clever and far-reaching metaphysical natural philosophy. Critically engaging with the unsubstantiated denial of metaphysics and several centuries-long attempts to overcome it, I demonstrate that by metaphysical thinking Boscovich arrived at his unique notion of attractive-repulsive force and gained insight into the structure of things, by which he anticipated, among other things, the theory of relativity and quantum physics. Although Boscovich greatly and successfully used quantitative methods while solving problems from geodesy, astronomy, optics, civil engineering statistics, hydraulic engineering and other fields - the most important parts of his natural sciences legacy, which made him transpose several centuries, are supported by geometric intuition and carried out mainly by qualitative methods, that is, metaphysical speculation. Also, I explain how for the creation and development of electromagnetism it was crucial to describe electromagnetic phenomena using Boscovich's unique law of force and his theory of the structure of matter, what was explicitly stated by the 'father of electromagnetism, James Clerk Maxwell. Boscovich would have never reached these ideas by the exact scientific method, only by metaphysically founded and guided 'proper thinking'.
\end{abstract}

\section{Key words}

Roger Joseph Boscovich, metaphysics, science, force, matter, theory of relativity, quantum physics

91

L. Lederman, D. Teresi, Božja čestica, str. 134-135.

92

Razumije se da svaka kvalitativna metoda nije samim time metafizička spekulacija, ali svaka metafizička spekulacija podrazumijeva svojevrsni kvalitativni pristup, gdje nema matematičkih proračuna i prirodoznanstvenih eksperimenata. O Boškovićevu kvalitativnom obuhvatu prirodnih zakonitosti matematičar Željko Marković izvrsno primjećuje: »Što je najbitnije dao Bošković u svojoj teoriji prirodne filozofije? To je izgradnja kvalitativne [kurzivom istaknuo M. M. L.] sheme za predočivanje mehaničkih i drugih fizičkih svojstava tvari, koja vodi do sasvim novoga gledanja na sastav tvari. Težište pri tom nije na nekom više ili manje dobrom kvantitativnom predočivanju iskustvenih pojava, nego na nepreglednim mogućnostima variranja te sheme u primjenama. Ta je omogućila Boškoviću da ubere one uberrimos fructus koji su i njega samoga iznenadili.«-Željko Marković, Ruđe Bošković, I. dio, JAZU, Zagreb 1968. str. 461

93

»Habes, amice Lector, Philosophiae Naturalis Theoriam ex unica lege virium deductam (...).« - ThPhN, »Čitaocu iz bečkog izdanja « (»Ad Lectorem ex editione Viennensi «), str. XIII. 